\title{
THE ETIOLOGY OF CHOLECYSTITIS AND GALL- STONES AND THEIR PRODUCTION BY THE INTRAVENOUS INJECTION OF BACTERIA *
}

\author{
EDWARD C. ROSENOW
}

From the Memorial Institute for Infectious Diseases, Chicago, and the Mayo Foundation, Rochester, Minnesota

The lodgment and growth of bacteria in the gallbladder have been considered chiefly as accidental, notwithstanding the fact that bacteriemia occurs in numerous diseases in which cholecystitis is absent. Attempts by investigators to produce cholecystitis by simple intravenous injection of various bacteria have usually resulted in failure. The typhoid bacillus, however, quite irrespective of its source, has given positive results in the hands of Blachstein, ${ }^{1}$ Welch, ${ }^{2}$ Cushing, ${ }^{3}$ Koch, ${ }^{4}$ Gay and Claypole, ${ }^{5}$ and Nichols. ${ }^{6}$

During the course of experiments ${ }^{7}$ with laboratory strains of streptococci, I noted that lesions of the gallbladder followed intravenous injection of these strains only when the virulence had attained a certain point. Two years ago I reported a case ${ }^{8}$ in which cholecystitis had occurred 10 days after tonsillitis, and in which a streptococcus had been isolated from the wall of the gallbladder, and from the centers of the newly formed gallstones. This streptococcus had shown a far greater affinity for the gallbladder in animals than had streptococci from other diseases. ${ }^{3}$

In this paper I wish to record the results of cultures by special methods from the liquid contents of the gallbladder, from the centers of gallstones, from the wall of the gallbladder, and from the adjoining lymph glands removed at operation, in a series of cases of cholecystitis, and the results of animal experiments with the bacteria thus isolated. These results, it is believed, throw definite light on the mechanism of the occurrence of cholecystitis and gallstones.

\section{Technic}

The gallbladder or adjacent lymph glands were removed aseptically with as little exposure to the air and skin as possible, covered at once with sterile gauze, and taken unopened to the laboratory. The contents were collected in pipets; a portion of the gallbladder $(0.5 \mathrm{~cm}$. by $1 \mathrm{~cm}$.) was excised, and one or more stones, if present, were saved for cultures. The pieces of tissue from

* Received for publication May 3, 1916. 
the gallbladder and the lymph glands were washed twice in salt solution, the surfaces flamed or seared with a blade, and then the tissue emulsified in a mortar in a specially devised sterile air chamber. ${ }^{10}$

Cultures from the gallstones were made from pulverized material taken from the centers by means of a small dental burr, after the surfaces had been seared with a blade. Control cultures from more superficial portions were made in some instances. The cultures were made in tall columns of liquefied ascites (10\%) dextrose (1\%) agar, in ascites dextrose broth, in litmus milk, and on blood-agar slants. In some instances pieces of sterile tissue, guinea-pig heart or kidney, were added to the bottom of the shake cultures in agar. The cultures were incubated at from 35 to $37 \mathrm{C}$. for at least 10 days before being discarded, and were examined daily.

The bacteria for injection were usually from single colonies in the shake cultures, and had been grown in tall columns $(12 \mathrm{~cm}$.) of ascites dextrose broth containing sterile tissue, for from 18 to 28 hours, centrifugated, the clear broth poured off, and the bacteria suspended in salt solution so that 1 c.c. contained the growth from 15 c.c. of the broth culture. The injections were made intravenously through a 23 -gauge needle with a glass syringe, sterilized by boiling. The portion of the suspension left over was preserved in the ice chest for further injections in case the results warranted further study. This method was found to preserve the elective property of the bacteria in the presence of pieces of sterile tissue for a longer time than repeated subcultures. In one instance it endured for as long as 20 months (Case 140). Blood-agar-plate cultures and smears were made from the suspensions at the time of the injections to prove the viability of the organisms at the time of injection and to be used in the study of cultural features. In most experiments the injections were made some hours after the feeding period. The dogs were fed meat and bread or dog biscuits, the rabbits and guinea-pigs liberal amounts of greens, bread, or oats and hay.

The autopsies were made as soon after death as possible. A careful inspection in a bright light aided with a hand lens was made for focal lesions. Cultures were made routinely from blood, bile, joint fluid, and the emulsified tissues of the wall of the gallbladder. The pieces of tissue saved for microscopical study were fixed in Kaiserling's solution, Zenker's solution, $10 \%$ formalin, or in $80 \%$ alcohol.

\section{RESULTS OF THE CULTURES IN HUMAN CHOLECYSTITIS}

Of the patients in whom sex was noted, 25 were females and 13 males. The youngest was 18 years of age, the oldest 68 . There were 28 between the ages of 30 and 60 years. The duration of symptoms in the different cases ranged between 6 weeks and 25 years.

The cultures were made from material removed at operation in 47 cases. The bile or other fluid content of the gallbladder (Table 1) was cultured in 29 cases, 13 of which showed no bacteria. In the remaining 16 cases the streptococcus was not found in pure culture, being found in conjunction with the colon bacillus in 5 instances, and with other bacteria in 2 . The colon bacillus was found in pure culture 4 times.

Cultures from the nuclei of the common types of gallstones were made in 33 cases, showing no bacteria. In the remaining 29 cases the 
streptococcus was isolated in pure culture in 17 , and the colon bacillus in pure growth in 1 . The streptococcus occurred with the colon bacillus in 3 cases, and with other bacteria in 4 . Cultures made from 4 typical cholesterin stones (not given in tables) showed no streptococci; 2 were sterile, 1 yielded a few colonies of a diphtheroid bacillus, and 1 the colon bacillus.

Cultures from the wall of the gallbladder were made in 32 cases, 5 of which were sterile. Of the remaining 27 the streptococcus was found in pure culture in 10 , the colon bacillus in 1 , mixtures of streptococcus and colon bacillus in 8 , and the streptococcus with other bacteria in 3 .

Of the cases in which the fluid contents were sterile the streptococcus was isolated from the wall of the gallbladder in 8 , and from the center of gallstones in 6 .

The adjacent lymph glands were cultured in 8 cases; 1 gave no bacteria, 4 showed pure cultures of the streptococcus, 1 the streptococcus and a diphtheroid bacillus, and 1 a pure culture of colon bacillus.

Bacillus welchii was found in conjunction with other bacteria in the gallstones in 7 cases, and in the wall of the gallbladder and in the adjacent lymph glands in 1 instance each. It was not obtained in cultures from the fluid contents. Staphylococcus aureus alone was present in the contents and wall in 1 case, and in mixture with the colon bacillus in 1 case of acute cholecystitis. Diphtheroid bacilli were found pure in the gallbladder wall in 1 case, and in mixture with streptococci in the contents in 1 , in the wall in 2 , and in a lymph gland in 1 . Fusiform bacilli were found in conjunction with the colon bacillus or the streptococcus in the contents and in the wall in 2 cases. Bacillus mucosus was found in conjunction with Staphylococcus aureus in the contents in 1 case, and in conjunction with the colon bacillus and the fusiform bacillus in the wall of the gallbladder in 1 case, both in acute cholecystitis. Unidentified strictly aerobic bacilli and cocci, which were found occasionally, were considered contaminations. The typhoid bacillus was isolated from the center of a gallstone in 1 case.

The cultures from the outer portion of the gallstones were sterile when the fluid contents were sterile, and contained a bacterial flora similar to that found in the fluid contents when the latter were infected. The nuclei of the stones, on the other hand, often yielded pure cultures of streptococci, irrespective of the bacterial flora of the fluid contents. In 12 cases the streptococcus was isolated both from the center of the stone and from the wall of the gallbladder. In 5 cases of advanced 
chronic cholecystitis without stones, streptococci were isolated from the wall of the gallbladder. In 5 cases of chronic catarrhal cholecystitis without stones, in which the changes were slight, streptococci were isolated in 1 , a few colon bacilli in 2 , and no bacteria in 2 . In 5 cases of chronic catarrhal cholecystitis with stones, the streptococcus was isolated from the center of the stones in 2 cases, and a diphheroid bacillus in 1 . In 9 cases of acute cholecystitis in the first attack or during an acute exacerbation of a chronic cholecystitis, cultures showed the streptococcus alone or in combination with other bacteria in the wall in 7 cases, and in the stones in 5 ; the colon bacillus was found in 4 of these, Bacillus mucosus in 2, and the staphylococcus in 2 . Streptococci were found in small numbers either in the stone or in the wall of the gallbladder in 4 cases in which the mucous membrane of the gallbladder presented the so-called strawberry appearance. ${ }^{11}$

The gross and microscopic changes in the gallbladders studied were of the usual character. Those in which there were chronic changes, and which had been removed during the quiescent interval, showed fibrosis with little cellular infiltration, while those in which there had been a recent acute attack had hemorrhages and marked infiltration, chiefly in the submucosa and subperitoneal coat. Cross sections at the apex of the gallbladder revealed no noteworthy changes in the nerve trunks. The eosinophilic infiltration of the fibrous tissue was often a striking picture. The bacteria were found in the areas of hemorrhage and infiltration in relatively large numbers, but were also demonstrated in the more or less dense fibrous tissue in the gallbladders with chronic changes only.

\section{Review of Important Cases and Animal Experiments}

Case 61

A woman, 59 years of age, who had suffered for 15 years from symptoms referable to the gallbladder or the stomach, was operated on during an exacerbation of symptoms August 11, 1914. The gallbladder, full of stones, and a gland the size of a navy-bean at the juncture of the cystic and common ducts, were removed. A rather large indurated ulcer also was found at the lesser curvature of the stomach. Cultures were made from a portion of the gallbladder wall, $0.5 \mathrm{~cm}$. square, showing what appeared to be an infarcted area, and from the bile, the lymph gland, and the centers of two of the stones.

August 12.-Tall tubes of ascites-dextrose and dextrose agar inoculated with the emulsion of the wall yielded altogether 28 colonies of streptococci, while those inoculated with the emulsion of the gland gave 5. All the colonies were in the upper three-fourths of the tubes. In one tube inoculated with a large amount of the emulsion of the gallbladder wall, there were 2 colonies of $B$. welchii. The centers of the gallstones yiklded a short-chained streptococcus in dextrose broth. The cultures from the bile remained sterile. Subcultures were 
made on blood-agar plates from 6 of the colonies from the wall of the gallbladder, from 2 from the gland, and from the growth in the broth inoculated with material from the centers of the stones. The rest of the colonies were not disturbed.

Aug. 13. - Blood-agar plates showed small grayish-green moist, but discrete, quite opaque colonies of short-chained streptococci in pure culture.

Aug. 25.-Subcultures from original colonies, which had grown to be $2 \mathrm{~mm}$. in diameter, were made, by means of small pipets, into the ustal flasks of ascites dextrose broth containing sterile tissue.

Aug. 26.-The broth showed a dense diffuse turbidity with slight sediment and marked acidity. After centrifugation, the supernatant broth was poured off, and the sediment suspended in $\mathrm{NaCl}$ solution to be injected into animals.

Sections through the infarcted area near the fundus showed leukocytic infiltration, and easily

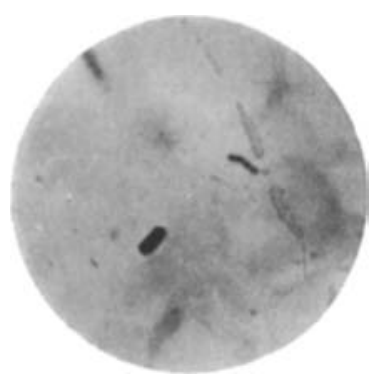

Fig. 1. Chain of streptococci and Bacillus welchii, causing infiltration in the gallbladder, Case 61 . Gram. Weigert. $\times 1200$. findable streptococci and B. welchii (Fig. 1). Cross sections at the apex of the gallbladder, near the juncture of the cystic duct. showed fibrosis of the interstitial tissue, thickening of the walls of the blood vessel, with moderate leukocytic and round-cell infiltration around blood vessels in the interstitial tissue and submucosa. A few diplococci were found in the areas of leukocytic infiltration. In the interstitial tissue leukocytes were chiefly eosinophils. Nerve trunks and the mucous membrane were quite free from changes.

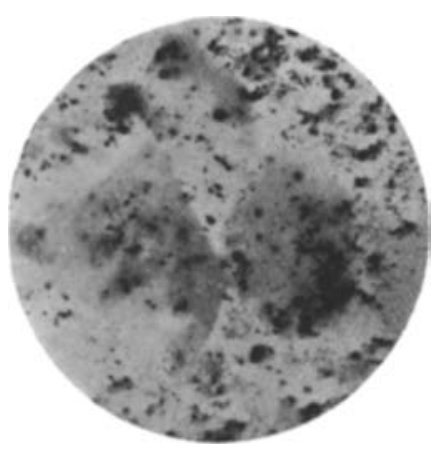

Fig. 2. Photograph of the ma. terial found in the hemorrhagic and infiltrated gallbladder of a dog (D 158) after repeated intravenous injections of streptococci. Black gallstones are embedded in the fiakes of mucopurulent material. Natural size.

the streptococcus isolated from the gland.

Intravenous injection into $1 \mathrm{dog}$ and 1 rabbit of the streptococcus from the gland, produced localized hemorrhages and edema in the gallbladders of both, while the streptococcus from the wall of the gallbladder as isolated, produced cholecystitis in 2 dogs injected, as well as in 2 dogs after 1 animal passage. Two of 3 rabbits developed no lesions in the gallbladder; the other had cholecystitis. In 1 rabbit and 2 of the dogs with cholecystitis were numerous small black gallstones imbedded in a thick black mucus containing bile (Fig. 2). The opening in the ampulla of Vater in the rabbit was plugged with a similar material. This is interesting because the gallbladder from which the strain was isolated was filled with stones proved to contain streptococci.

$R a b b i t$ 794. - Injected intravenously, August 26, with the growth from 45 c.c. of an ascites-dextrose-tissue-broth culture of

Aug. 28.-It seemed well. Killed. Gallbladder distended with thick greenishblack bile, in which were a large number of black particles from 0.5 to $1.5 \mathrm{~mm}$. 
in diameter. Ducts dilated; bile not to be expressed until the plug of mucus containing soft stones was removed from the ampulla. Wall of the gallbladder thickened and edematous. Few small hemorrhages at the base of the tricuspid valve and in the lung. Joint fluid slightly turbid.

Aug. 29.-Liver, blood, and bile cultures sterile.

Dog 105.-Injected intravenously, August 26, with the growth from 90 c.c. of an ascites-dextrose-tissue-broth culture of the streptococcus from the wall of the gallbladder.

Aug. 29.-The animal seemed well. Chloroformed. No noteworthy lesions anywhere except a marked hemorrhagic cholecystitis. Gallbladder wall edematous and hemorrhagic, particularly at the apex; from 0.3 to $0.6 \mathrm{~cm}$. in thickness. Mucous membrane edematous, in places ulcerated and separated from the serous coat by marked hemorrhage; covered with thick adherent bile-stained mucus. A number of small hemorrhages along the cystic duct, but none along the common and hepatic ducts. Joint fluid clear.

Aug. 31.-Cultures in blood agar from the bile, blood, liver, and joint fluid were sterile, while those from the wall yielded a pure growth of streptococci in ascites dextrose agar and broth, and on blood-agar plates. Sections of the gallbladder showed marked hemorrhage in the subperitoneal layer and moderate leukocytic infiltration. This was most marked in the submucosa and in the peritoneal coat, where a moderate number of gram-positive diplococci were found.

\section{CASE 85}

A man, 60 years of age, who had not been ill until after a misstep from a ladder 5 months previous to examination. Since then he had had pain in the epigastrium, dizziness, and for a time chills and fever. At operation on August 15,1914 , there were disclosed a distended and somewhat thickened gallbladder, marked pancreatitis of the head of the pancreas, and enlarged lymph glands along the cystic and common ducts. The gallbladder contained a large amount of dark bile and masses of tenacious mucus, in which were embedded a very large number of black particles, biliary sand, varying in size from a pin point to a grain of wheat. In smears from the bile and from the centers of the stones was what appeared to be B. fusiformis. In cultures from the bile, from the centers of 2 of the stones, and from the wall of the gallbladder there were streptococci and colon bacilli. The organism resembling $B$. fusiformis which was found in smears failed to grow. Two dogs and 1 rabbit injected intravenously with the streptococcus soon after isolation, developed cholecystitis. In the 2 dogs in which injections were made into the portal vein, there were no lesions of the gallbladder or of other organs. The 2 dogs in which the general circulation had been injected, had mild arthritis in addition to the cholecystitis, and 1 had hemorrhage of the stomach.

Dog 107.-Injected, August 26, in the leg vein with the growth from 60 c.c. of an ascites-dextrose-tissue-broth culture of the streptococcus from the gallbladder wall in the shake cultures in ascites dextrose agar.

Aug. 28.-Seemed well. Chloroformed. Three circumscribed hemorrhages in the mucous membrane of the gallbladder, and 1 in the mucous membrane of the lesser curvature of the stomach.

Aug. 29.-Cultures from blood, joint fluid, and bile were sterile on blood agar, but those from the blood in dextrose broth gave short-chained streptococci.

Dog 113.- On August 26, a small radicle of the portal vein was injected with the growth from 60 c.c. of an ascites-dextrose-broth culture of the streptococcus as isolated from the gallbladder wall. 
Aug. 29.-Seemed well. Chloroformed. A localized peritonitis and plastic adhesions at the point of injection. In the gallbladder and elsewhere, no changes.

Aug. 31.-Cultures on blood agar of joint fluid, blood, liver, and bile were sterile, while the broth culture of the bile yielded a pure growth of a shortchained streptococcus.

CASE 120

A man, 55 years of age, suffering with chronic cholecystitis and chronic duodenal ulcer was operated on August 20, 1914. There were found a gallbladder with marked sclerosis and thickening, a large indurated ulcer of the duodenum just outside the pylorus, adherent to the head of the pancreas, and a pea-sized lymph gland draining the ulcer. The gallbladder, containing bile and one stone $2 \mathrm{~cm}$. in diameter, and the gland were removed and cultured.

Cross sections of the apex of the gallbladder revealed marked fibrosis of the submucous muscularis and peritoneal coat, thickening of the blood vessels, hemorrhagic infiltration chiefly of the peritoneum and subperitoneum, atrophy of the mucous membrane, and a few diplococci in the hemorrhagic areas.

Cultures from the bile were negative. In the center of the stone were streptococci, colon bacilli, anl B. welchii. The gallbladder wall and the lymph gland draining the ulcer yielded pure cultures of the streptococcus. These strains were similar in appearance, but those from the lymph gland produced long chains and colonies with a distinct green zone on blood-agar plates, while those from the ulcer produced grayish colonies with no tinge of green.

The streptococcus from the gallbladder wall produced cholecystitis in 2 dogs injected, but no other noteworthy lesions, while the streptococcus from the lymph gland draining the ulcer produced hemorrhage and ulcer of the stomach in 1 of 2 dogs, and in both of 2 rabbits. The dog without lesions in the stomach or duodenum showed no other lesions. One rabbit, in addition to ulcer, had mild arthritis and a few hemorrhages in the subcutaneous tissue and muscles.

Dog 114--Injected intravenously, August 28, with the growth from 30 c.c. of an ascites-dextrose-broth culture of the streptococcus isolated from the wall of the gallbladder.

Aug. 31.-Seemed well. Chloroformed. A number of small hemorrhages from 0.3 to $0.8 \mathrm{~cm}$. in diameter and edema of the gallbladder, especially along its attachment to the liver. No changes in bile ducts, appendix, stomach, duodenum, or pancreas.

Sept. 1.-Blood-agar-plate cultures from the bile gave 6 colonies of streptococci, and cultures from the gallbladder wall yielded 3 colonies of streptococci and 4 colonies of colon bacilli. Blood and joint fluid sterile.

Dog 109.--Injected intravenously, August 26, with the growth from 120 c.c. of an ascites-dextrose-broth culture of the streptococcus isolated from the gland draining the ulcer.

Aug. 28.-Seemed well. Chloroformed. No gross lesions except numerous small punctate hemorrhages scattered over 3 circumscribed areas in the pyloric ring. In the centers of 2 of these the mucous membrane was necrotic and ulcerated.

Rabbit 700.-Injected intravenously, August 26, with the growth from 15 c.c. of an ascites-dextrose-broth culture of the streptococcus isolated from the gland draining the ulcer. 
Aug. 28.-Killed. No gross lesions except ulcer, $0.2 \mathrm{~cm}$. by $0.4 \mathrm{~cm}$., at the juncture of the middle and lower thirds of the stomach, near the lesser curvature. Base hemorrhagic; mucous membrane ulcerated and undermined.

Aug. 29.-Cultures from blood, joint fluid, and bile were negative, while the culture from the ulcer yielded approximately 100 colonies of streptococci.

\section{CAse 135}

A woman, 68 years of age, with chronic cholecystitis and an acute exacerbation. The attack of cholecystitis with chills and fever had begun 10 days previously. Symptoms of stones in the gallbladder dated back 15 years. The patient had never been jaundiced. At operation, August 22, 1914, there were disclosed a greatly thickened gallbladder containing many stones and mucopurulent material free from bile, an inflamed and dilated common duct, the size of the small intestine, containing 1 large stone, and enlarged lymph glands along the cystic and common ducts. The gallbladder and 1 lymph gland were removed and cultures made.

Aug. 23.-In the cultures from the centers of two of the stones, from the wall of the gallbladder, and from the mucopurulent material, were streptococci and colon bacilli, while in those from the gland there were streptococci only. There were more colonies of colon bacilli than of streptococci from the mucopus and from the centers of the stones, while the wall of the gallbladder showed a preponderance of streptococci.

Cross section of the apex of the gallbladder showed fibrosis, marked dilation of blood vessels, hemorrhage and marked leukocytic infiltration, especially in the submucosa, and numerous bacilli and diplococci both in the mucous membrane and in the hemorrhagic peritoneal coat.

One dog injected intravenously with a mixture of the streptococcus and the colon bacillus as isolated from the stone, developed a marked cholecystitis. Three dogs and 1 rabbit injected with the streptococcus from the stone, all showed cholecystitis. One dog and 1 rabbit in which a small branch of the portal vein had been injected, disclosed no lesions in the gallbladder. One dog in which the gallbladder had been injected directly, developed only a localized cholecystitis and peritonitis around the place of puncture. The streptococci appeared to have been washed out by the bile without having produced lesions of the mucous membranes of the gallbladder or of the bile ducts.

Dog 102.-Injected intravenously, August 24, with the growth from 150 c.c. of an ascites-dextrose-broth culture of a mixture of streptococci and colon bacilli from the center of the gallstone.

Aug. 26.-Seemed well. Chloroformed. Gallbladder wall hemorrhagic in areas and extremely edematous; from 0.4 to $0.8 \mathrm{~mm}$. in thickness. Pressure caused marked oozing of a blood- and bile-tinged fluid from the cut surface. Mucous membrane covered with an adherent mucus and necrotic material, but not ulcerated. No hemorrhages in the liver; marked hemorrhage in the first two centimeters of the common duct, and many small hemorrhages in the head of the pancreas. Lymph glands along the ducts enlarged and hemorrhagic on the cut surface. No other focal lesions except hyperemia of the mucous membrane of the small intestine and slight turbidity of the joint fluid.

Aug. 27.-Cultures from the joint fluid negative. The blood and the bile in blood agar yielded only colon bacilli; in broth, both colon bacilli and streptococci. The gallbladder wall and lymph gland gave colon bacilli and streptococci. 


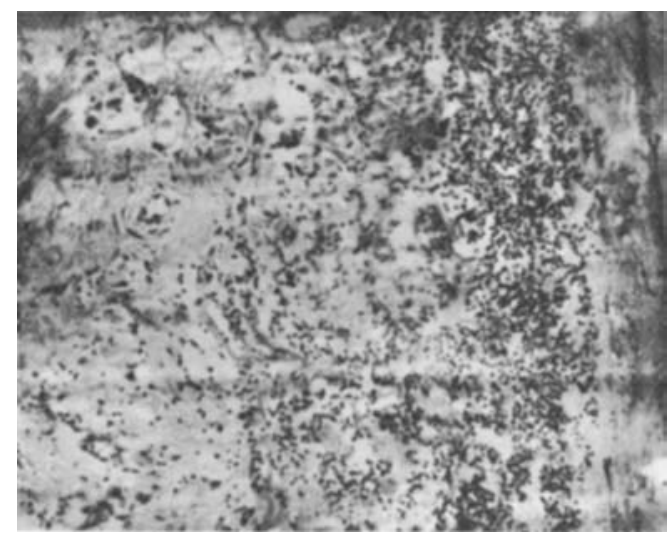

Fig. 3. Section of a gallbladder, Case 140, showing marked fibrosis, marked subperitoneal hemorrhage, and leukocytic infiltration. Hematoxylin-eosin. $\times 30$.

Dog 108.-Injected intravenously, August 26, with the growth from 90 c.c. of an ascites-dextrose-tissue-broth culture of a pure growth of the streptococcus from the gallstone.

Aug. 29.-Seemed ill. Chloroformed. The gallbladder contained many circumscribed hemorrhages surrounded by moderate edema. These were most marked over the fundus, and along the attachment of the gallbladder to the liver. Mucous membrane hyperemic with a few small hemorrhages. Liver, ducts, and pancreas appeared normal. Joint fluid distinctly turbid.

Aug. 31.-Cultures from the bile and the liver gave a pure growth of the streptococcus, while the blood and the joint fluid remained sterile.

\section{CASE 140}

A woman, 34 years of age, with acute and chronic cholecystitis. The symptoms suggesting gallstones and cholecystitis had been present for 5 years, but the last attack, during which she had intense pain in the epigastrium, accompanied by a moderate temperature and the development of a leukocytosis, had continued for 20 days. The patient was operated on August 22, 1914, as the symptoms were subsiding. There was an adherent edematous hemorrhagic and much thickened gallbladder, containing 6 stones and much pus. One of the stones was impacted in the cystic duct. The appendix was thin and fibrous, its lumen obliterated. The gallbladder was removed and cultures made from a portion of the wall $1 \mathrm{~cm}$. square from near the fundus, from the center of one stone, and from the fluid contents.

Aug. 23.-The shake cultures in ascites dextrose agar from the center of one of the stones showed approximately 7,200 colonies of the typical streptococcus; those from the emulsion of the wall of the gallbladder yielded 40 colonies of the same streptococcus (Fig. 8); the pus was sterile.

Aug. 24.-Blood-agar-plate cultures from single colonies in the shake culture showed a pure growth of small grayish nonadherent nonhemolyzing colonies of streptococci.

Sections across the apex of the gallbladder disclosed marked fibrosis, thickening of blood vessels, atrophy of mucous membrane, hemorrhagic infiltration, 
chiefly in the submucosa and the peritoneal coat, numerous eosinophils in connective tissue, and a moderate number of gram-staining diplococci in hemorrhagic areas in the submucosa and the subperitoneum (Figs. 3 and 4 ).

The streptococcus from the stone and that from the wall of the gallbladder were each injected, in the second generation, into 1 dog and 1 rabbit. Both dogs (100 and 101) developed marked cholecystitis,

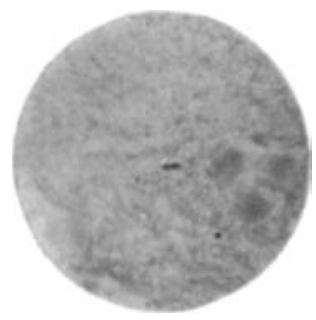

Fig. 4. Diplococcus in hemorrhagic area shown in Fig. 3. Gram-Weigert. $X$ 1000 .

\section{1esions. A 30 -c.c. portion} but the rabbits appeared well 48 hours after injection. The dog injected with the culture from the gallbladder had 2 small hemorrhages in the tricuspid valve, hemorrhages in the diverticulum of Vater, and 1 hemorrhage in the gallbladder. The other had 2 small hemorrhages in the tricuspid valve and a few in the subcutaneous tissue, but no lesions of the gallbladder or bile ducts. The strain from the wall of the gallbladder after cultivation on blood agar for 10 days, and then in ascites dextrose broth, was injected into 3 dogs. All three seemed well soon after injection, and were chloroformed, 2, 4, and 6 days later, respectively. Dog 128 had a few fading hemorrhages in the fundus of the gallbladder. The others had no lesions. A 30-c.c. portion of the suspension containing pieces of tissue in the second culture, which was injected into 1 rabbit and $1 \mathrm{dog}$ and which produced marked lesions of the gallbladder, was placed in the ice chest August 24, 1914, and the bacteria allowed to remain in latent life undisturbed until March 15, 1915. Blood-agar-plate cultures then contained many small nonhemolysing grayish colonies exactly as when isolated.

March 16.-Two dogs were injected, one with 3 c.c. and the other with 12 c.c. of this old suspension. Both died in 24 hours, showing marked hemorrhage and edema of the gallbladder, and hemorrhages of the stomach, duodenum, and intestinal tract. The one receiving 12 c.c. had, in addition, hemorrhage and edema of the cystic and common ducts. In the blood of both were pure cultures of a slightly green-producing streptococcus; in the bile and the edematous fluid were countless numbers of the injected streptococcus.

The streptococci in the first subculture in ascites dextrose broth from the old suspension were injected March 18 into 2 dogs. Both developed lesions in the gallbladder, one a few hemorrhages in the stomach, and the other in the pancreas. Both dogs were well when chloroformed 48 hours after injection; the blood was sterile.

A culture in ascites dextrose broth made directly from the edematous gallbladder of the dog which had been injected with $12 \mathrm{c}$.c. of the old suspension, was injected into $1 \mathrm{dog}$ and 1 rabbit. Both developed marked lesions of the gallbladder. The strain from the dog's gallbladder, injected into 1 rabbit, gave rise to no lesions of the gallbladder, but gave rise to multiple arthritis. The strain from the rabbit's gallbladder was injected into 3 dogs and 2 rabbits in doses ranging from 2 to 75 c.c. All the dogs and 1 of the rabbits developed cholecystitis. Two weeks after the injection the gallbladders of 1 rabbit and 1 dog showed healing cholecystitis with distinct fibrous thickening.

The fact that such small amounts of the old suspension were so toxic and showed the same striking affinity for the gallbladder as did this strain in fresh 
cultures, afforded excellent opportunity to test whether or not there was present in the streptococcus cultures a filterable virus, and whether or not streptococci from cholecystitis having marked affinity for the gallbladder produce soluble products with the power to cause lesions electively in the gallbladder. A dog injected with 2 c.c. of the old filtered suspension-which had been proved sterile by cultures in ascites dextrose broth and on blood agar-had a number

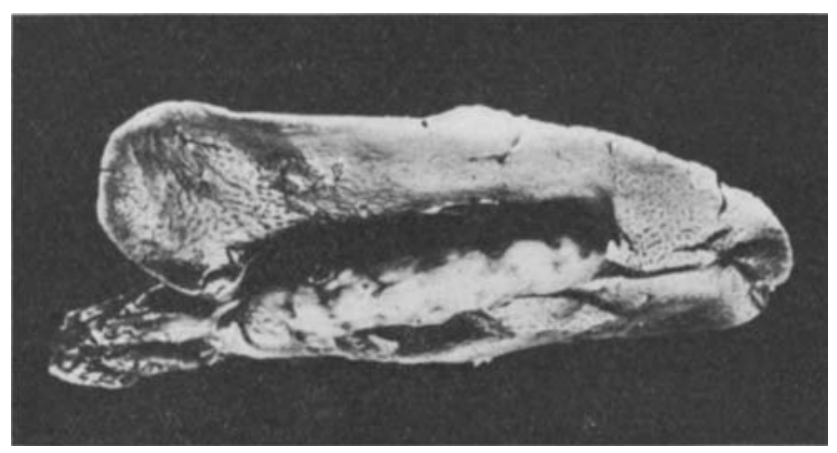

Fig. 5. Cholecystitis in a rabbit (R 188) 5 days after intravenous injection of the streptococcus shown in Fig. 8, after it had been kept in the ice-chest for 7 months and then passed through one animal (D275). Natural size.

of small hemorrhages in the peritoneal coat near the apex of the gallbladder and $a$ few in the mucous membrane near the fundus. Cultures from one hemorrhagic area yielded a pure growth of the streptococcus, which passed through the filter in small numbers, because subsequent cultures from the centrifugated sediment of a portion showed the streptococcus. Filtrates of the first subculture of this aged suspension and of the 24-hour-broth culture, after 1 and 2 animal passages, were injected into 5 dogs and 1 rabbit; only 1 dog developed lesions of the gallbladder. Cultures from the hemorrhagic gallbladder and from the blood in this dog remained sterile, and 45 c.c. of this sterile culture from the hemorrhagic area in the gallbladder failed to produce lesions in the gallbladder on subsequent injection. A filterable virus, therefore, appears absent, but there seem to be soluble products in these young cultures which in distinctly smaller amounts than are required of similar filtrates from other streptococci, tend to produce lesions in the gallbladder when injected intravenously.

The piece of tissue added originally to the dextrose broth and contained in the suspension which was kept in the ice chest 9 months, was preserved in the bottom of a test tube in the ice chest until March, 1916, 20 months after the cultures had been made. Subcultures from this were now made on blood agar and into ascites dextrose broth. One ringtail monkey, $1 \mathrm{dog}$, and 1 rabbit were injected with the growth in ascites dextrose broth. All seemed well 72 hours after injection, when they were chloroformed. All had developed lesions of the gallbladder (Fig. 6) but practically no lesions in other organs. The streptococcus was found in the hemorrhagic area in moderate numbers (Fig. 7).

Dog 100.-Injected intravenously, August 24, with the growth from 45 c.c of an ascites-dextrose-tissue-broth culture. 


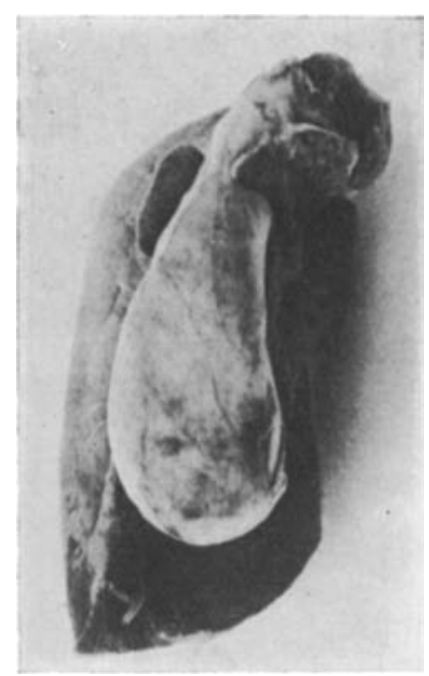

Figure 6

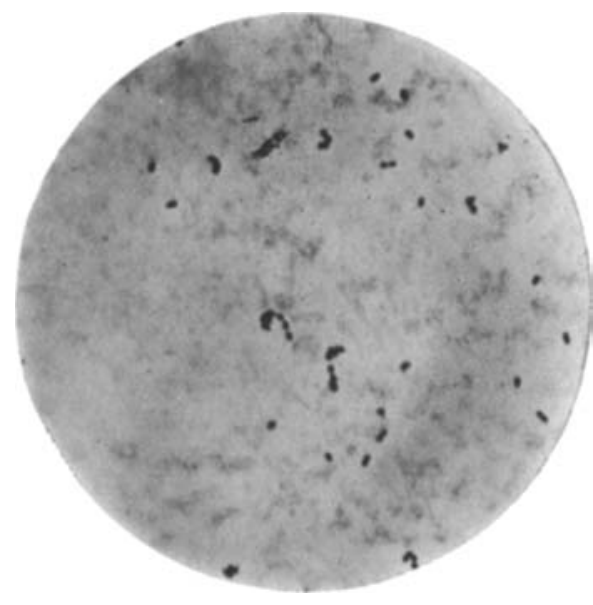

Figure 8

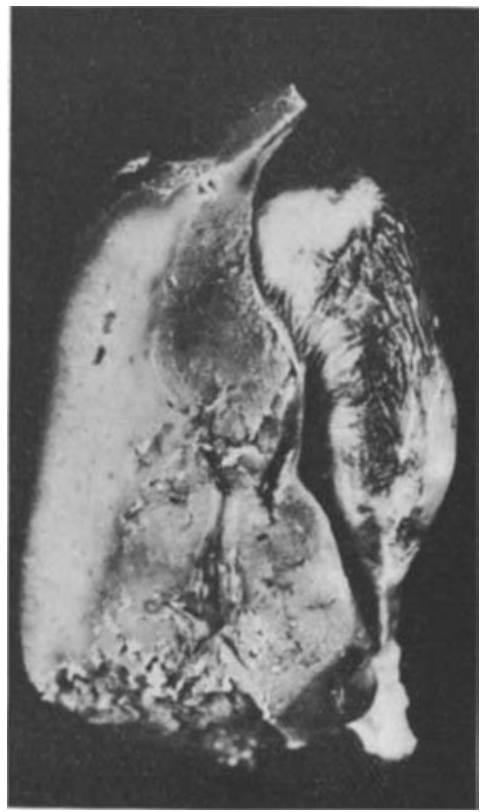

Figure 9

Figure 7

Fig. 6. Gallbladder in a dog (D 430 ) 72 hours after intravenaus injection of a subculture of the streptococcus shown in Fig. 8, after it had been kept in the ice-chest for 20 months. About natural size.

Fig. 7. Two diplococci in the hemorrhagic area in the subperitoneum of the dog's gallbladder shown in Fig. 6 . One diplococcus in partial focus. Gram-Weigert. $\times 1200$

Fig. 8. A smear of a 24-hour culture in ascites dextrose broth of a streptococcus isolated from the gallbladder in Case 140. The morphology, size, and grouping are typical of the various strains isolated in cholecystitis, Gram stain, $\times 1200$.

Fig. 9. Hemorrhage and infiltration in the gallbladder in Dog 100, 48 hours after intravenous injection of the streptococcus shown in Fig. 8 . Three-fourths natural size. 

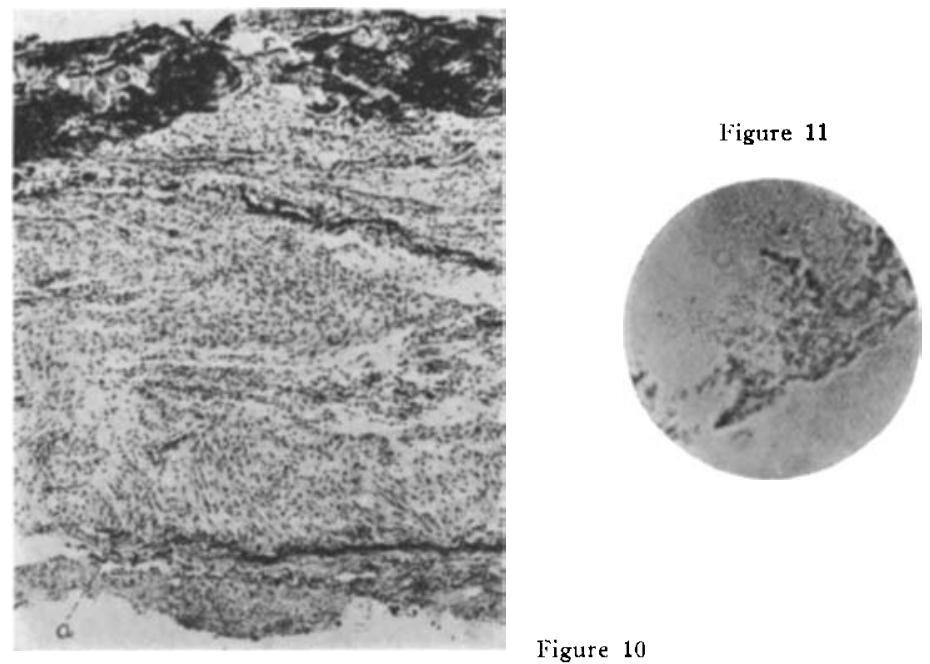

Fig. 10. Section of the gallbladder of Dog 101, 48 hours after intravenous injection of the streptococcus shown in Fig. 8. Marked leukocytic infiltration in the submucosa, between the muscular bundles in the muscular bundles in the muscular coat, and in the peritoneum. The latter is covered with a thick layer of exudate, rich in red blood corpuscles and leuko. cytes. Hematoxylin and eosin. $\times 40$.

Fig. 11. Diplococci in the peritoneal exudate shown in Fig. 10. Gram.Weigert. $\times 1200$.

Aug. 26.-Seemed well. Chloroformed. Gallbladder filled with turbid bile; the wall edematous and hemorrhagic (Fig. 9). Mucosa normal. No hemorrhages along the ducts or in the liver, and no other noteworthy lesions.

Aug. 27.-Cultures from blood, kidney, liver, bile, and joint-fluid sterile.

Dog 101.- Injected intravenously, August 24, with the growth from 90 c.c. of an ascites-dextrose-tissue-broth culture of the streptococcus isolated from gallbladder wall.

Aug. 26.-Seemed well. Chloroformed. Acute hemorrhagic cholecystitis. The wall of the gallbladder was covered in areas with a fibrinous exudate and contained the large subperitoneal hemorrhages, particularly over the fundus, associated with moderate edema. No noteworthy changes in the mucous membrane, Ducts free from hemorrhage. Lymph glands along the cystic and common ducts enlarged and hemorrhagic on the cut surface. Joint fluid slightly turbid.

Aug. 27.-Cultures from blood, joint fluid, bile, and liver were sterile, while those from the infiltrated wall of the gallbladder contained the streptococcus. Sections through a hemorrhagic area near the fundus of the gallbladder showed a layer of fibrinous exudate rich in leukocytes covering the peritoneal coat, leukocytic infiltration of the peritoneal and subperitoneal layer, especially in localized areas surrounding blood vessels and dilated lymph spaces (Fig. 10), and an aggregation of leukocytes in a rather large blood vessel in the subperitoneum. The mucous membrane and the aggregation of lymphoid cells in the submucosa were free from lesions and revealed no leukocytic infiltration.

A moderate number of diplococci and a few short chains were in the exudate covering the peritoneum and in the areas showing leukocytic infiltration (Fig. 11). 
Dog 128.-Injected intravenously, September 3, with the growth from 75 c.c. of an ascites-dextrose-broth culture of the streptococcus isolated from the wall of the gallbladder 10 days previously.

Sept. 5.-Seemed well. Chloroformed. A few small hemorrhages in the mucous membrane of the stomach and a number of small fading subperitoneal hemorrhages over the fundus of the gallbladder. No noticeable associated edema or infiltration. Gallbladder distended with greenish bile and viscid mucus.

Sept. 7.-Cultures on blood agar from blood and bile were sterile, while those from the blood in dextrose broth yielded a pure culture of the streptococcus.

\section{CASE 166}

A young man, with acute cholecystitis and pancreatitis of 10 days' duration, was operated on Oct. 12, 1914. A markedly edematous pus-containing gallbladder was found, embedded in a mass of fibrinous adhesions. The pus from the lumen and a portion of the wall of the gallbladder were removed and cultured. Smears from the former showed what appeared to be colon bacilli and streptococci.

Oct. 13.-Cultures from the wall of the gallbladder and from the pus gave 3 varieties of colonies, one of which appeared to be colon bacilli, another $B$. mucosa, and a third smaller and more opaque variety resembled staphylococci.

Oct. 15.-Subcultures on Loeffler's serum of the staphylococcus revealed a moderate amount of gray growth. The mucoid colonies were made up of strictly aerobic encapsulated gram-negative nonmotile bacilli, which did not produce gas in dextrose-agar stabs, while the colon-bacillus-like colonies showed typical nonencapsulated motile gas-producing bacilli.

A suspension in $\mathrm{NaCl}$ solution of pus failed to produce lesions in the one dog injected. A mixture of the staphylacoccus and of $\mathrm{B}$. mucosus injected into 1 dog produced numerous hemorrhages in the stomach, the small intestine, and the medulla of the kidney, and acute hemorrhagic pancreatitis with fat necrosis, while the one rabbit which was injected died with marked hemorrhages in the stomach and the intestine. The staphylococcus after 1 animal passage was injected into 2 dogs and 1 rabbit. Both dogs had pancreatitis and 1 had cholecystitis, while the rabbit had endocarditis and myocarditis.

Dog 190.-Injected intravenously, Oct. 15, with the growth from 15 c.c. of an ascites-dextrose-broth culture of the staphylococcus and the encapsulated bacillus mixed.

Oct. 16.-Found dead, body warm. Numerous small hemorrhages and erosions in the mucous membrane of the stomach, marked enteritis, and marked hemorrhages in the medulla of the kidney. Pancreas hemorrhagic and studded with numerous irregular white areas of fat necrosis.

Oct. 17.-The blood and the pancreas showed staphylococci in pure culture.

Dog 195.-Injected intravenously, Oct. 21, with the growth from 5 c.c. of an ascites-dextrose-broth culture of the staphylococcus after 2 animal passages.

Oct. 23.--Seemed ill.

Nov. 6.-Seemed well but had lost in weight. Chloroformed. Pancreas swollen, hard, and hyperemic. Bile thick and dark, containing mucus in which were embedded numerous black particles. On the wall of the gallbladder was an opaque band of fibrous thickening, running from the apex over the fundus.

Nov. 11.-Cultures from the bile on dextrose agar yielded a large number of gram-staining cocci singly, in twos, and in groups. The blood was sterile. 
CASE 230

A woman, 32 years of age, was operated on Dec. 30, 1914. Gallbladder edematous and distended with mucopurulent material, in which were embedded numerous small stones. Chills and fever, intense pain and tenderness over the gallbladder had begun 5 days beiore the operation. There had been 4 milder attacks during the previous 9 months.

Jan. 2.-In the aerobic cultures from scrapings from the wall of the gallbladder, from the stone, and the pus, were colon bacilli only, while in the anaerobic cultures there were colon bacilli and B. fusiformis.

Two dogs and 2 rabbits were injected with the growth from ascites dextrose broth containing colon bacilli only; both dogs and 1 rabbit developed marked cholecystitis. The rabbit and $1 \mathrm{dog}$ had, in addition, lesions of the cystic and common ducts. The other rabbit had small hemorrhages in duodenum, stomach, and appendix. In $1 \mathrm{dog}$, injected intravenously with the anaerobic culture on blood agar, a marked diffuse cholecystitis and cholangeitis were produced. The dog in which an injection was made directly into the gallbladder developed only a localized edema of the gallbladder and peritonitis around the point of puncture. The colon bacillus isolated from the edematous gallbladder of Dog 204, produced marked hemorrhagic enteritis and pancreatitis in the one dog injected.

Dog 204.- Injected intravenously, Dec. 31, with the growth from 45 c.c. of an ascites-dextrose-broth culture from the pus.

Jan. 2.-Found dead. Gallbladder markedly edematous; $0.7 \mathrm{~cm}$. in thickness, and covered with a hemorrhagic fibrinous exudate. Two areas had become gangrenous. In smears from the edematous fluid were a large number of colon bacilli. In the liver were areas of hemorrhage; the mucous membrane of the intestinal tract was hemorrhagic; the intestinal contents were bloody; and the pericardial sac contained bloody fluid. Sections showed marked hyperemia of

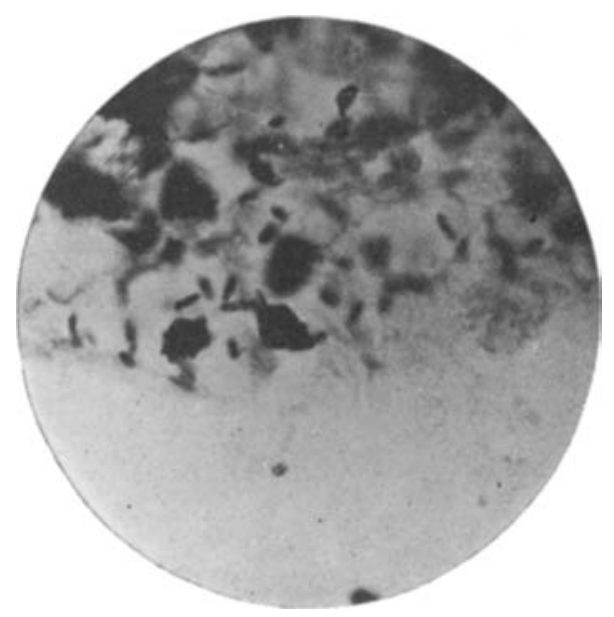

Fig. 12. Colon bacilli in the wall of a markedly edematous gallbladder (D 104) 24 hours after intravenous injection of colon bacilli from acute cholecystitis in man. Gram-Weigert (partial decolorization). $\times 1200$. 
TABLE 1

Summary of the Results of Cultures in Cholecystitis

\begin{tabular}{|c|c|c|c|c|c|c|}
\hline \multirow[b]{2}{*}{ Case } & \multirow{2}{*}{\multicolumn{2}{|c|}{$\underset{\text { Sex and }}{\text { Age }}$}} & \multirow{2}{*}{$\begin{array}{l}\text { Anatomlc } \\
\text { Diagnosis }\end{array}$} & \multirow{2}{*}{$\begin{array}{l}\text { Duration } \\
\text { of Symp- } \\
\text { toms }\end{array}$} & \multicolumn{2}{|c|}{ Results of Cultures From } \\
\hline & & & & & $\begin{array}{l}\text { Blle or Other } \\
\text { Fluld Contents of } \\
\text { Gallbladder }\end{array}$ & Gallstones \\
\hline 41 & & .. & Cholecystitis with stones & $\ldots \ldots \ldots \ldots$ & n................ & Oolon bacillus \\
\hline 55 & & . & $\begin{array}{l}\text { Chronic cholecystitis with } \\
\text { stones }\end{array}$ & $\ldots \ldots \ldots \ldots$ & $\cdots$ & $\begin{array}{l}\text { Streptococcus (one } \\
\text { colony) }\end{array}$ \\
\hline 58 & $\mathbf{F}$ & 50 & $\begin{array}{l}\text { Ohronic cholecystitis with } \\
\text { stones and appendleitis }\end{array}$ & 20 years & $\begin{array}{l}\text { Streptococcus and } \\
\text { colon bacillus }\end{array}$ & Streptococcus...... \\
\hline 59 & $\mathbf{F}$ & 56 & $\begin{array}{l}\text { Chronic cholecystitls and } \\
\text { chronic appendicitis }\end{array}$ & $\begin{array}{c}2 \text { or } 3 \\
\text { years }\end{array}$ & $\cdots \ldots \ldots, \ldots, \cdots \cdots$ & (........... \\
\hline 60 & $\mathbf{F}$ & 36 & $\begin{array}{l}\text { Chronic catarrhal chol. } \\
\text { ecystitls }\end{array}$ & 10 years & Negative............ & $\cdots$ \\
\hline 61 & $\mathbf{F}$ & 59 & $\begin{array}{l}\text { Chronic cholecystitis with } \\
\text { stones }\end{array}$ & 15 years & Sterile............. & Streptococeus...... \\
\hline 66 & $\mathbf{M}$ & 75 & Chronic cholecystitis...... & 9 years & $\begin{array}{l}\text { Streptococcus and } \\
\text { colon bacillus }\end{array}$ & 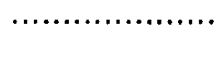 \\
\hline 67 & $\mathbf{M}$ & 56 & Ohronic cholecystitis...... & 10 years & $\cdot$ & $\cdots \ldots \ldots, \ldots, \ldots, \ldots$ \\
\hline 68 & $\mathbf{F}$ & 50 & $\begin{array}{l}\text { Chronic cholecystitis with } \\
\text { stones }\end{array}$ & 16 years & n................. & $\begin{array}{l}\text { Streptococcus and } \\
\text { B. Welchlf }\end{array}$ \\
\hline 70 & $\mathbf{F}$ & 28 & $\begin{array}{l}\text { Ohronie cholecystitis with } \\
\text { stones }\end{array}$ & 2 years & Negative........... & $\begin{array}{c}\text { Streptococeus } \\
\text { colonles })\end{array}$ \\
\hline 73 & $\mathbf{M}$ & 52 & $\begin{array}{l}\text { Chronic catarrhal chol- } \\
\text { ecystltis and appendicitis }\end{array}$ & 12 years & Negative........... & (n.......... \\
\hline 79 & $\mathbf{M}$ & 68 & $\begin{array}{l}\text { Chronic cholecystitis with } \\
\text { stones }\end{array}$ & 24 years & Staphylococcus.... & Streptococcus...... \\
\hline 85 & $\mathbf{M}$ & 60 & $\begin{array}{l}\text { Cholecystitis and pancre- } \\
\text { atitis }\end{array}$ & 5 months & $\begin{array}{l}\text { Streptococeus, co- } \\
\text { lon bacillus, and } \\
\text { fusiform bacillus }\end{array}$ & $\begin{array}{l}\text { Streptococeus and } \\
\text { colon bacillus }\end{array}$ \\
\hline 91 & $\mathbf{M}$ & 48 & $\begin{array}{l}\text { Gangrenous gallbladder } \\
\text { and encysted stone }\end{array}$ & 9 months & $\cdots$ & $\begin{array}{l}\text { Streptococcus } \\
\text { colonies })\end{array}$ \\
\hline 93 & $\mathbf{M}$ & 32 & $\begin{array}{l}\text { Pancreatitis, cholecystitis } \\
\text { and appendieftis obliter- } \\
\text { ans }\end{array}$ & .......... & Negative.......... & 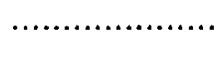 \\
\hline 94 & $\mathbf{M}$ & 58 & $\begin{array}{l}\text { Cholecystitls, probably } \\
\text { secondary to perforating } \\
\text { duodenal ulcer }\end{array}$ & 20 years & Colon bacillus..... & $\begin{array}{l}\text { Colon bacillus and } \\
\text { streptococcus }\end{array}$ \\
\hline 98 & $\mathbf{F}$ & 50 & $\begin{array}{l}\text { Chronic cholecystitis with } \\
\text { stones }\end{array}$ & 12 years & $\begin{array}{l}\text { Streptococeus and } \\
\text { diphtherold ba- } \\
\text { cillus }\end{array}$ & Streptococcus...... \\
\hline 99 & $\mathbf{M}$ & 24 & Chronic cholecystltis...... & 5 months & Negativa........... & n.................. \\
\hline 101 & $\mathbf{F}$ & 41 & $\begin{array}{l}\text { Chronie cholecystitis with } \\
\text { stones }\end{array}$ & 21/2 years & Colon bacillus..... & $\begin{array}{l}\text { Streptococeus and } \\
\text { B. Welchil }\end{array}$ \\
\hline 102 & $\mathbf{M}$ & 55 & $\begin{array}{l}\text { Chronic catarrhal chol- } \\
\text { ecystitis }\end{array}$ & 6 years & Colon bacillus..... & n.................... \\
\hline 108 & $\mathbf{F}$ & 52 & $\begin{array}{l}\text { Chronic cholecystitis with } \\
\text { stone }\end{array}$ & 25 years & $*$ & Streptococeus...... \\
\hline 115 & $\mathbf{M}$ & 44 & $\begin{array}{l}\text { Chronic cholecystitis with } \\
\text { stones }\end{array}$ & 3 years & Negative.......... & Negative........... \\
\hline 117 & $\mathbf{F}$ & 45 & $\begin{array}{l}\text { Acute cholecystitis with } \\
\text { common duct stone }\end{array}$ & $\begin{array}{l}4 \text { or } 5 \\
\text { years }\end{array}$ & Colon bacillus..... & Streptococcus...... \\
\hline 120 & $\mathbf{M}$ & 55 & $\begin{array}{l}\text { Cholecystitis with stone } \\
\text { and duodenal ulcer }\end{array}$ & 7 years & Negative........... & $\begin{array}{l}\text { Streptococcus, co- } \\
\text { lon bactllus, and } \\
\text { B. Welchii }\end{array}$ \\
\hline
\end{tabular}


TABLE 1-Continued

Summary of the Results of Cultures in Cholecystitis

\begin{tabular}{|c|c|c|}
\hline \multicolumn{2}{|c|}{ Results of Cultures From } & \multirow[b]{2}{*}{ Remarks } \\
\hline $\begin{array}{l}\text { Gallbladder } \\
\text { Wall }\end{array}$ & $\begin{array}{l}\text { Adjacent Lymph } \\
\text { Glands }\end{array}$ & \\
\hline 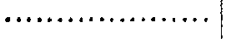 & $\ldots, \ldots, \ldots, \ldots, \ldots$, & …… \\
\hline $\begin{array}{l}\text { Streptococeus } \\
\text { colonies) }\end{array}$ & (n.......... & \\
\hline Streptococcus..... & $\ldots \ldots \ldots \ldots \ldots \ldots$ & Cultures from obliterated appendix, sterile \\
\hline $\begin{array}{l}\text { Streptococeus and } \\
\text { colon bacillus }\end{array}$ & n............... & $\begin{array}{l}\text { Cultures from appendix, streptococcus and colon } \\
\text { bacillus }\end{array}$ \\
\hline Negative........... & $\ldots \ldots+\ldots, \ldots+\cdots$, & Gallbladder showed doubtful lesions \\
\hline $\begin{array}{l}\text { Streptococcus (27 } \\
\text { colonies) and B. } \\
\text { Welchil }\end{array}$ & $\begin{array}{l}\text { Streptococcus } \\
\text { colonies) }\end{array}$ & $\begin{array}{l}\text { Cultures made from infarcted area near fundus of } \\
\text { gallbladder }\end{array}$ \\
\hline $\begin{array}{l}\text { Streptococeus and } \\
\text { colon bacillus }\end{array}$ & 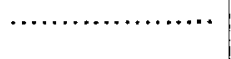 & Gallbladder had been drained for 3 years \\
\hline & $\begin{array}{l}\text { Streptococcus and } \\
\text { diphtherold ba- } \\
\text { cillus }\end{array}$ & $\therefore$ \\
\hline & & 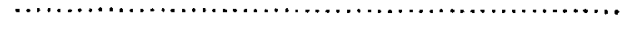 \\
\hline Streptococcus..... & $\ldots \ldots \ldots \ldots \ldots \ldots$ & Strawberry gallbladder \\
\hline Negative.......... & $\ldots \ldots \ldots+\cdots \cdots+\cdots$ & $\begin{array}{l}\text { Thickening of gallbladder slight. Wall of appendix } \\
\text { showed colon bacillus and streptococeus }\end{array}$ \\
\hline Negative............ & $\ldots \ldots \ldots \ldots \ldots \ldots, \ldots$ & Gallbladder contracted tightly on single stone \\
\hline $\begin{array}{l}\text { Streptococeus and } \\
\text { colon bacillus }\end{array}$ & $\cdots$ & $\begin{array}{l}\text { Large amount of thick tenacious dark material in } \\
\text { gallbladder, in which was imbedded much "gand" } \\
\text { and a number of calculi, size of wheat grains }\end{array}$ \\
\hline $\begin{array}{l}\text { Streptococeus, co- } \\
\text { Ion bacillus, and } \\
\text { fusiform ba- } \\
\text { clllus }\end{array}$ & $\ldots$. & $\begin{array}{l}\text { First attack of cholecystitis in which stone was prob. } \\
\text { ably formed, } 10 \text { yesrs before. Second attack in } \\
\text { which stone became encysted, } 31 / 2 \text { months betore }\end{array}$ \\
\hline $\begin{array}{l}\text { Streptococcus and } \\
\text { diphtheroid ba- } \\
\text { cllius }\end{array}$ &. & $\begin{array}{l}\text { Tip of appendix, portion just beyond oblterated } \\
\text { lumen, showed colon bacillus and streptococcus }\end{array}$ \\
\hline $\begin{array}{l}\text { Streptococeus } \\
\text { colonies) }\end{array}$ & …...... & Uleer had probably existed for 20 years \\
\hline $\begin{array}{l}\text { Streptococeus (120 } \\
\text { colonjes) }\end{array}$ & $\cdots \cdot$ & $\begin{array}{l}\text { Symptoms of cholecystitis for } 12 \text { years. Wall of gall- } \\
\text { bladder thickened, mucous membrane destroyed. } \\
\text { Many large and small stones }\end{array}$ \\
\hline $\begin{array}{l}\text { Streptococeus or } \\
\text { diphtherold ba- } \\
\text { cillus }\end{array}$ & $\cdots$ & Wall of gallbladder moderately thickened \\
\hline$\cdots \cdots \cdots+\cdots \cdots \cdots+\cdots$ & $\cdots \cdots$ & Wall of gallbladder only slightly thickened \\
\hline Colon bacillus..... & $\ldots \ldots \ldots \ldots \ldots \ldots$ & Gallbladder only slightly thickened \\
\hline $\begin{array}{l}\text { Streptococcus and } \\
\text { colon bacillus }\end{array}$ & .. & $\begin{array}{l}\text { Typhoid fever } 30 \text { years before; symptoms referable to } \\
\text { stomach ever since, worse recently. Gallbladder } \\
\text { wall thickened }\end{array}$ \\
\hline Staphylocoecus.... & & $\begin{array}{l}\text { Symptoms suggestive of appendicitis. No evidence of } \\
\text { recent inflammation of gallbladder. Wall not mueh } \\
\text { thickened. Stones small }\end{array}$ \\
\hline $\begin{array}{l}\text { B. Welchii and } \\
\text { colon bacillus }\end{array}$ & $\begin{array}{l}\text { B. Welcbii and } \\
\text { colon bacillus }\end{array}$ & $\begin{array}{l}\text { Patient had chills and fever at time of operation, } \\
\text { which promptly disappeared afterward }\end{array}$ \\
\hline $\begin{array}{l}\text { Streptococcus } \\
\text { colonies) }\end{array}$ & $\begin{array}{l}\text { Streptococcus (one } \\
\text { colony) }\end{array}$ & $\begin{array}{l}\text { Duodenal ulcer markedly indurated with partial ob- } \\
\text { struetion to pylorus. Gallbladder and duodenum } \\
\text { adherent }\end{array}$ \\
\hline
\end{tabular}


TABLE 1-Continued

Sumarary of the Results of Cultures in Cholgcystitis

\begin{tabular}{|c|c|c|c|c|c|c|}
\hline \multirow[b]{2}{*}{ Case } & \multirow{2}{*}{\multicolumn{2}{|c|}{$\begin{array}{l}\text { Sex and } \\
\text { Age }\end{array}$}} & \multirow{2}{*}{$\begin{array}{l}\text { Anatomic } \\
\text { Diagnosis }\end{array}$} & \multirow{2}{*}{$\begin{array}{l}\text { Duration } \\
\text { of Symp- } \\
\text { toms }\end{array}$} & \multicolumn{2}{|c|}{ Results of Cultures From } \\
\hline & & & & & $\begin{array}{l}\text { Bile or Other } \\
\text { Fluld Oontents of } \\
\text { Gallbladder }\end{array}$ & Gallstones \\
\hline 122 & & 49 & $\begin{array}{l}\text { Chronie catarrhal chol- } \\
\text { ecystitis with stones }\end{array}$ & 17 years & Negative........... & Negative........ \\
\hline 124 & $\mathbf{F}$ & 39 & $\begin{array}{l}\text { Chronic cholecystitis with } \\
\text { stones }\end{array}$ & 22 years & $\begin{array}{l}\text { Streptococeus and } \\
\text { colon bacillus }\end{array}$ & B. Welchii...... \\
\hline 128 & $\mathbf{F}$ & 68 & $\begin{array}{l}\text { Chronte eatarrhal chol- } \\
\text { ecystitis with stones }\end{array}$ & .......... & Negative.... & • \\
\hline 182 & $\mathbf{M}$ & 38 & $\begin{array}{l}\text { Chronie appendicitis and } \\
\text { catarrhal cholecystitis }\end{array}$ & 14 years & Negative.......... & ${ }^{\circ}$ \\
\hline 135 & $\mathbf{F}$ & 68 & $\begin{array}{l}\text { Acute and chronic chol- } \\
\text { ecystitis with stones }\end{array}$ & 15 years & $\begin{array}{l}\text { Streptococeus and } \\
\text { colon bacillus } \\
\text { (many colonies, } \\
\text { mostly colon ba: } \\
\text { cillus) }\end{array}$ & $\begin{array}{l}\text { Streptococcus and } \\
\text { colon bacillus } \\
\text { (many colonies, } \\
\text { mostly colon ba- } \\
\text { cillus) }\end{array}$ \\
\hline 138 & $F$ & 39 & $\begin{array}{l}\text { Chronic cholecystitis with } \\
\text { stones }\end{array}$ & 5 years & n................ & $\begin{array}{l}\text { Streptococcus (one } \\
\text { colony) }\end{array}$ \\
\hline 140 & $\mathbf{F}$ & 34 & $\begin{array}{l}\text { Acute and chronic chol- } \\
\text { ecystitis with stones }\end{array}$ & $\begin{array}{l}5 \text { or } 6 \\
\text { years }\end{array}$ & Negative........... & $\begin{array}{l}\text { Streptococcus } \\
\quad(7,200 \text { colonies })\end{array}$ \\
\hline 166 & $\mathbf{M}$ & .. & $\begin{array}{l}\text { Acute cholecystitis and } \\
\text { pancrestitis }\end{array}$ & $\ldots \ldots \ldots$, & $\begin{array}{l}\text { Colon bacillus, } B \text {. } \\
\text { mueosus, and } \\
\text { stapbylocoecus }\end{array}$ & $\cdots \cdot$ \\
\hline 168 & $\mathbf{F}$ & $\cdots$ & $\begin{array}{l}\text { Empyema of gallbladder } \\
\text { with stones }\end{array}$ & & Sterile.. & Streptococcus...... \\
\hline 230 & $\mathbf{F}$ & 32 & $\begin{array}{l}\text { Subacute cholecystitis. } \\
\text { Empyema of gallbladder }\end{array}$ & & $\begin{array}{l}\text { Colon bacillus and } \\
\text { fusiform baeillus }\end{array}$ & 이 \\
\hline 494 & $\mathbf{F}$ & 41 & $\begin{array}{l}\text { Chronic eatarrhal chol. } \\
\text { ecystitis with stones }\end{array}$ & & $\cdots$ & $\begin{array}{l}\text { Streptococcus and } \\
\text { B. Welchli }\end{array}$ \\
\hline 497 & $\mathbf{F}$ & 43 & $\begin{array}{l}\text { Chronie cholecystitis with } \\
\text { stones }\end{array}$ & & (n........ & $\cdots \cdots \cdot$ \\
\hline 500 & $\mathbf{F}$ & 35 & $\begin{array}{l}\text { Ohronic catarrhal ehol- } \\
\text { ecystitis with stones }\end{array}$ & &. & $\begin{array}{l}\text { Diphtheroid-like } \\
\text { streptococeus }\end{array}$ \\
\hline 503 & $\mathbf{F}$ & 60 & $\begin{array}{l}\text { Subacute cholecystitis with } \\
\text { ston } 4 \mathrm{~B}\end{array}$ & & $\begin{array}{l}\text { Streptococcus and } \\
\text { colon bacillus }\end{array}$ & Negative \\
\hline 523 & $\mathbf{F}$ & 37 & $\begin{array}{l}\text { Chronic catarrhal chol- } \\
\text { ecystitis. Chronic catar- } \\
\text { rhal appendicitis }\end{array}$ & $\cdot$ & & \\
\hline 570 & $\mathbf{F}$ & 18 & $\begin{array}{l}\text { Chronic catarrhal chol- } \\
\text { eeystitis with stones }\end{array}$ & $\cdots$ & Sterile..... & $\begin{array}{l}\text { B. subtilis (2 colo- } \\
\text { nies, contamina- } \\
\text { tjon) }\end{array}$ \\
\hline 576 & $\mathbf{F}$ & 54 & $\begin{array}{l}\text { Chronie eholecystitis with } \\
\text { stones. Appendicitis ob- } \\
\text { literans }\end{array}$ & & *. & $\cdots$ \\
\hline $86 \theta$ & $\mathbf{F}$ & 62 & $\begin{array}{l}\text { Subacute cholecystitis with } \\
\text { stones }\end{array}$ & & Sterile.. & $\begin{array}{l}\text { Streptococcus, co- } \\
\text { lon bacillus, B. } \\
\text { Welchil }\end{array}$ \\
\hline 971 & .. & .. & Cholecystitis... & $\cdots$ & & Streptococcus \\
\hline 977 & $\because$ & .. & Cholecystltis with stones.. & & & Streptococcus \\
\hline 984 & 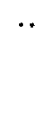 & .. & Cholecystitis with stones.. & .... & & $\begin{array}{l}\text { Onidentifled gram- } \\
\text { positive spore- } \\
\text { bearing bacillus } \\
\text { and typhoid ba- } \\
\text { cillus }\end{array}$ \\
\hline 988 & $\because$ & 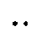 & Cholecystitis with stones.. & 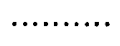 & $\ldots$ & Streptococcus \\
\hline 999 & *. & .. & Cholecystitis with stones.. & $\cdots$ & $\cdots$ & Streptococcus \\
\hline D & $\because$ & * & Oholecystitis with stones.. & & & Negative... \\
\hline
\end{tabular}


TABLE 1-Continued

Summary of the Results of Cultures in Cholecystitis

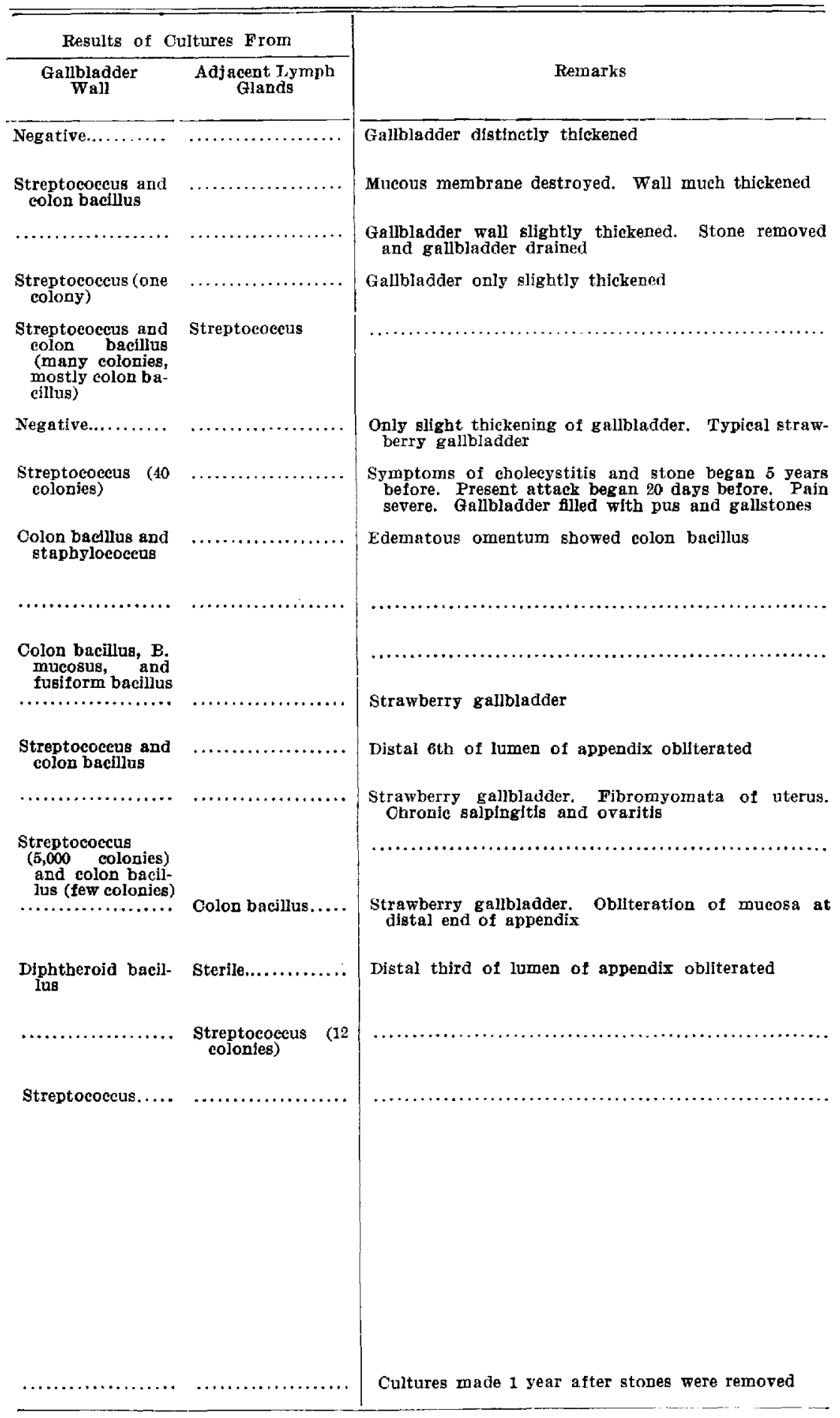


vessels, hemorrhage, leukocytic infiltration, edema, poorly staining nuclei of the fixed tissue cells, and numerous colon bacilli (Fig. 12).

Jan, 4.-Cultures from the bile, wall of the gallbladder, liver, and pericardial fluid gave colon bacilli in pure growth.

Dog 205.-Injected intravenously, Jan. 2, with the growth from 1 bloodagar slant.

Jan. 4.-Seemed fairly well. Chloroformed. Marked edema and hemorrhage of the gallbladder and of the cystic and common ducts. Mucous membrane edematous, hemorrhagic, gangrenous in areas, and covered with a thick adherent mucus. Stomach, duodenum, and intestinal tract showed no noteworthy changes. Joint fluid clear.

\section{RESULTS OF ANIMAL EXPERIMENTS}

The foregoing details will serve to illustrate the results obtained in other cases. In Table 2 is given a summary of the animal experiments made with strains from cholecystitis.

Of animals injected with the strains when isolated, $79 \%$ developed lesions of the gallbladder. This is in marked contrast to an average

TABLE 2

Elective Localization of Streptococci from Cholecystitis

\begin{tabular}{|c|c|c|c|c|c|c|c|}
\hline \multirow{2}{*}{\multicolumn{2}{|c|}{ Source of Streptococci }} & \multirow{2}{*}{ Strains } & \multirow{2}{*}{$\begin{array}{l}\text { Animals } \\
\text { Injected }\end{array}$} & \multicolumn{4}{|c|}{$\begin{array}{l}\text { Percentage of Animals Showing } \\
\text { Lesions in }\end{array}$} \\
\hline & & & & $\begin{array}{l}\text { Appen- } \\
\text { dix }\end{array}$ & $\begin{array}{c}\text { Stomach } \\
\text { Hemor- } \\
\text { rhage }\end{array}$ & $\begin{array}{l}\text { Duode- } \\
\text { num } \\
\text { Uleer }\end{array}$ & $\begin{array}{c}\text { Gall- } \\
\text { bladder }\end{array}$ \\
\hline Oholecystitis & 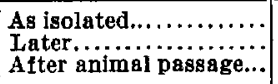 & $\begin{array}{r}16 \\
5 \\
4\end{array}$ & $\begin{array}{l}53 \\
14 \\
16\end{array}$ & $\begin{array}{r}0 \\
14 \\
0\end{array}$ & $\begin{array}{l}29 \\
28 \\
31\end{array}$ & $\begin{array}{l}16 \\
14 \\
13\end{array}$ & $\begin{array}{r}79 \\
7 \\
56\end{array}$ \\
\hline
\end{tabular}

incidence of lesions in the gallbladder of $11 \%$ as previously pointed out, $^{9}$ and to an incidence of $3 \%$ in 396 animals following injection of bacteria from sources other than cholecystitis. Later, that is after cultivation on artificial media for a time, this affinity was found to have largely disappeared, just as it tends to disappear after successive animal passages, lesions in the gallbladder occurring in $7 \%$ and $56 \%$ of the animals respectively (Table 1 ). If, however, the bacteria are placed in latent life, as occurs in the single colonies in shake cultures, or in $\mathrm{NaCl}$ suspensions containing tissue in the ice chest, the characteristic affinity may be retained for a long time. Thus the streptococcus from Case 140 lost nearly all its affinity for the gallbladder after cultivation on blood agar for 10 days, whereas when kept in the ice chest in $\mathrm{NaCl}$ solution its affinity for the gallbladder was marked 8 and 20 months later. 
The incidence of pancreatitis, following injection of the strains from cholecystitis as isolated, was $5 \%$; after cultivation $0 \%$; and after animal passage $19 \%$. In some of the animals, especially those injected with strains after animal passage, there were noted simultaneously lesions of the gallbladder, bile ducts, and pancreas (Fig. 13).

Elective affinity for the gallbladder was shown by 16 strains of streptococci from cholecystitis as isolated. Most of these were isolated from the wall of the gallbladder, 3 from the centers of gallstones, and 1 from an adjacent lymph gland. Only $22 \%$ of the animals, chiefly rabbits, died from the effects of the injection; the rest were killed. The colon bacilli from 3 cases of cholecystitis with stones, in which streptococci also were isolated, showed no special affinity for the gallbladder, while 2 strains from acute cholecystitis in which streptococci were absent, showed marked affinity for the gallbladder. This suggests that they were secondary invaders in the former, and the cause of cholecystitis in the latter. The staphylococcus

TABLE 2-Continued

Elective Localization of Streptococci from Cholecystitis

\begin{tabular}{|c|c|c|c|c|c|c|c|c|c|}
\hline \multicolumn{10}{|c|}{$\begin{array}{l}\text { Percentage of Animals Showing } \\
\text { Lesions in }\end{array}$} \\
\hline $\begin{array}{l}\text { Pan- } \\
\text { cress }\end{array}$ & $\begin{array}{l}\text { Intes- } \\
\text { tines }\end{array}$ & Joints & $\begin{array}{l}\text { Endo- } \\
\text { cardl- } \\
\text { um }\end{array}$ & $\begin{array}{l}\text { Ieri- } \\
\text { cardi- } \\
\text { um }\end{array}$ & $\begin{array}{l}\text { Myo- } \\
\text { cardi- } \\
\text { um }\end{array}$ & Mugeles & Bidney & Lung & Skin \\
\hline $\begin{array}{r}5 \\
0 \\
19\end{array}$ & $\begin{array}{r}19 \\
0 \\
13\end{array}$ & $\begin{array}{l}17 \\
21 \\
25\end{array}$ & $\begin{array}{l}12 \\
14 \\
10\end{array}$ & $\begin{array}{l}0 \\
0 \\
0\end{array}$ & $\begin{array}{r}2 \\
0 \\
13\end{array}$ & $\begin{array}{l}9 \\
0 \\
0\end{array}$ & $\begin{array}{r}5 \\
7 \\
13\end{array}$ & $\begin{array}{l}8 \\
0 \\
6\end{array}$ & $\begin{array}{l}3 \\
0 \\
0\end{array}$ \\
\hline
\end{tabular}

from an acute case showed marked affinity for the gallbladder. The lesions following injection of the colon bacillus and staphylococcus were not confined so strikingly to the gallbladder as in the case of the streptococcus. Mixed cultures in ascites dextrose broth of streptococci and colon bacilli from the gallbladder in cholecystitis were injected directly into 11 animals; of these, $5(46 \%)$ developed lesions of the gallbladder, while the appendix and stomach showed no noteworthy lesions. These findings are again in marked contrast to those following injections of the primary mixed cultures of strepococci and colon bacilli from appendicitis and ulcer of the stomach. The mixed cultures from appendicitis produced lesions of the appendix in $30(78 \%)$ of 37 rabbits, of the stomach or duodenum in 9, and of the gallbladder in 4 . Those from ulcer produced lesions of the stomach or duodenum in $5(62 \%)$ of 8 animals, of the gallbladder in 1 , and of the appendix in 
none. The tendency to infect the tissues in animals corresponding to the diseased tissues from which the organisms were isolated is shown, therefore, even by mixed cultures. It should be stated, however, that in most of these the streptococcus determined the elective localization.

The elective localization of the bacteria from the tonsils was tested in the case of 3 patients who had recurring attacks of cholecystitis. The cultures from 2 , one during an acute exacerbation, the other 3 days after cholecystectomy, were injected into 2 dogs and 4 rabbits. Both dogs and 2 of the rabbits developed striking lesions in the gallbladder, the rabbits showing lesions in the muscles in addition; the other 2 rabbits had ulcer of the stomach. The cultures from the tonsils of the 3rd patient, 1 week after an acute attack, did not produce lesions of the gallbladder, but produced myositis in 1 dog and 1 rabbit.

In a summary of the cultures from animals with lesions in the gallbladder following injection of streptococci, it was found that the streptococci were isolated from the blood at the time of autopsy in only 16 of 62 animals; from the bile in 14 of 66 ; from the wall of the gallbladder in 15 of 21 ; and from the joint-fluid in 6 of 38 . In 3 instances cultures from the bile or wall of the gallbladder showed a secondary invasion of colon bacilli (Case 120, Dog 114). The number of colonies from the wall of the gallbladder, the seat of experimental cholecystitis, ranged from a few to 8,000 .

The strains of streptococci from myositis, ulcer of the stomach, and after one or more animal passages, were especially prone to cause lesions in the gallbladder (Figs. 15, 16, 17, 18, 20, and 22).

Definite formation of gallstones, resembling in appearance those found in one of the patients in this series, was noted altogether in 6 rabbits and 3 dogs with cholecystitis (Fig. 2). In some of these animals, streptococci were present in the gallstones in pure form when absent in the surrounding fluid and salt-solution washings.

The milder lesions in experimental cholecystitis consisted of circumscribed areas of subperitoneal hemorrhage, fibrinous deposit on the peritoneum, aggregation of leukocytes in and surrounding blood vessels (Fig. 10), while the marked changes often consisted of extreme edema from 24 to 48 hours after injection chiefly of strains from acute cholecystitis. In the former there was often marked leukocytic infiltration (Fig. 10), but in the latter this was usually absent. The nuclei of the cells in fixed tissue stained faintly, and the mucous membrane appeared necrotic (Fig. 16). Sections of these gallbladders cut transversely at the apex often showed extreme dilatation of lymph vessels and tissue 


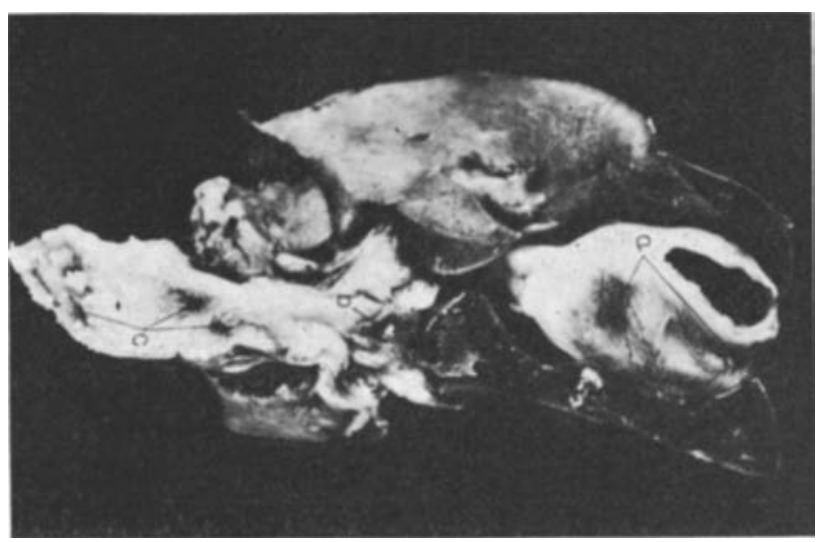

Fig. 13. Hemorrhages in the gallbladder (a), common duct (b), and head of the pancreas (c), in a $\operatorname{dog}$ (D 144) 4 days after intravenous injection of a streptococcus isolated from ulcer of the stomach in man (Case 52), after 1 animal passage. Natural size.

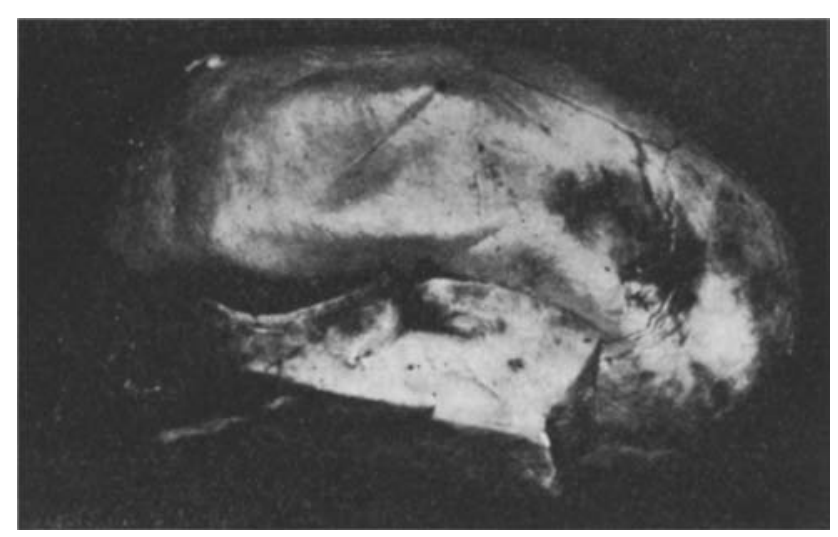

Fig. 14. Localized hemorrhagic cholecystitis and hepatitis in a dog (D 139) 3 days after intravenous injection of a streptococcus from duodenal ulcer in man (Case 112). Natural size.

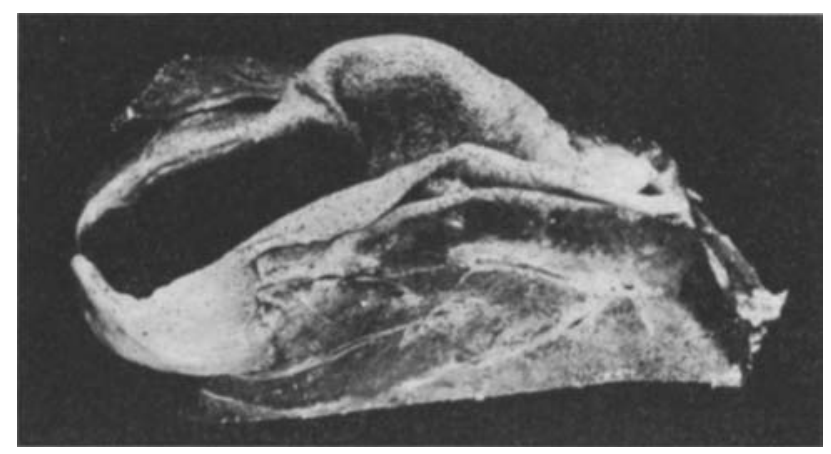

Fig. 15. Edema of the gallbladder in a $\operatorname{dog}$ (D 142) 24 hours after injection of the streptococcus from the gallbladder shown in Fig. 14. Natural size. 
spaces, which were filled with edematous fluid (Fig. 16). In size the arteries usually appeared normal or distinctly dilated.

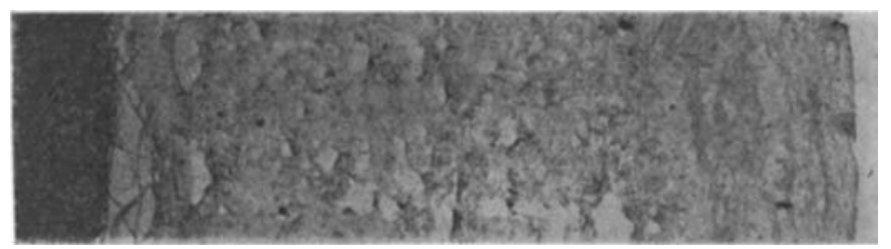

Fig. 16. Cross section of the gallbladder in a dog (D 63) 9 days after intravenous injection of a streptococcus from human ulcer of the stomach and cholecystitis (Case $J$ ). Extreme edema, dilatation of the lymph channels and connective tissue spaces, and almost complete absence of staining of nuclei. The stomach of this dog showed 2 ulcers near the pyloric end, and the mucous membrane of the gallbladder was ulcerated in several ateas. Hematoxylin-eosin. $\times 20$.

There was a striking difference between the location of lesions in the gallbladders of dogs following injection of streptococci, and that following injection of colon bacilli. Following the former, the lesions were chiefly in the peritoneal and muscular coat, the mucous membrane being involved secondarily and only when the lesions were marked; following the latter, the mucous membrane was often necrotic or sloughed, and the peritoneal and muscular coat involved but slightly.

The demonstration of bacteria both in cholecystitis in man and in the experimental form of the disease was difficult, even where the cultures showed large numbers of colonies. This appeared to be especially true when the edematous fluid was stained with bile. In some of these colonies the bacteria appeared swollen and partially digested (Fig. 17).

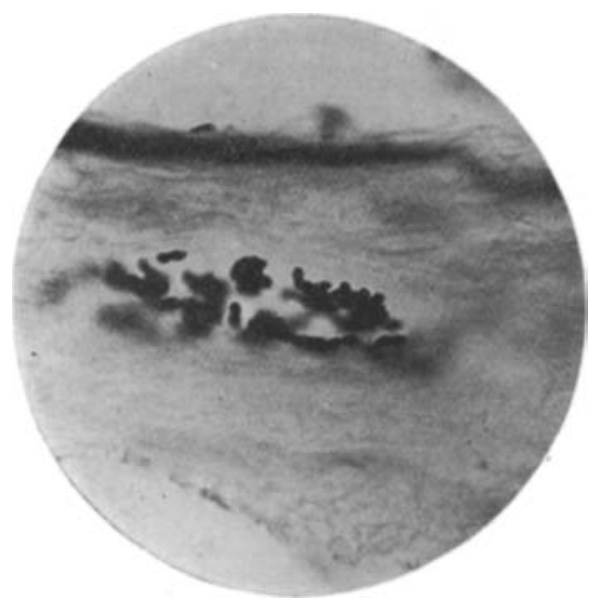

Fig. 17. Numerous swcllen diplococci in a lymph channel beneath the peritoneum in the edematous gallbladder shown in Fig. $15 . \times 1200$. 
THE STREPTOCOCCI FROM CHOLECYSTITIS

All strains produced acid in dextrose and maltose, and none produced acid in inulin, or in the controls of the sugar-free broth; hence these are omitted in Table 3 . The broth was prepared in the standard way from beef infusion, $1 \%$ of the various test substances added, the resultant media rendered $0.6 \%$ acid to phenolphthalein, sterilized frac-

TABLE 3

Fermentative Reactions of Streptococci from Cholecystitis

\begin{tabular}{|c|c|c|c|c|c|c|}
\hline Date & Strain & Lactose & Succharose & Raffinose & Mannite & Salicin \\
\hline $\begin{array}{r}6 / 7 / 15 \\
3 / 17 / 15 \\
3 / 28 / 16 \\
1 / 21 / 15 \\
12 / 21 / 15 \\
6 / 7 / 15 \\
12 / 20 / 15 \\
12 / 21 / 15 \\
\\
1 / 21 / 15 \\
12 / 20 / 15 \\
1 / 21 / 15 \\
3 / 28 / 16 \\
1 / 21 / 15 \\
1 / 21 / 15 \\
12 / 20 / 15 \\
1 / 21 / 15 \\
12 / 20 / 15 \\
2 / 5 / 15 \\
2 / 3 / 16\end{array}$ & $\begin{array}{c}140 \\
140 \\
140 \\
140^{2} \\
140^{2} \\
55 \\
58 \\
58 \\
58^{*} \\
85 \\
85 \\
85^{2} \\
61 \\
91 \\
91 \\
91 \\
91^{*} \\
91^{*} \\
91^{*} \\
93 \\
98 \\
135^{*} \\
135^{*} \\
135^{*} \\
135^{*} \\
135^{2} \\
135^{2} \\
999^{*} \\
999^{*}\end{array}$ & $\begin{array}{c}+++ \\
\frac{+}{0.7} \\
\overrightarrow{0} \\
+ \\
0 \\
0.3 \\
+ \\
++ \\
1.4 \\
++ \\
++ \\
++ \\
+ \\
1.6 \\
+ \\
+ \\
1.1 \\
++ \\
+ \\
+ \\
+ \\
0.3 \\
++ \\
+ \\
0.3 \\
+++ \\
0.9\end{array}$ & $\begin{array}{c}+++ \\
+++ \\
0.4 \\
0 \\
++ \\
\ddot{1.5} \\
\because \\
0 \\
\because \\
\because \\
\ddot{1.3} \\
\because \\
2.7 \\
\because \\
\because \\
1.0 \\
\because \\
\ddot{1.5} \\
7.5\end{array}$ & $\begin{array}{c}0 \\
0 \\
0.2 \\
\overline{0} \\
0 \\
0 \\
0 \\
0 \\
0 \\
0 \\
0 \\
+ \\
0 \\
\overrightarrow{1.0} \\
0 \\
0.1 \\
0 \\
\overrightarrow{0} \\
0 \\
0 \\
0 \\
0 \\
0 \\
0.2\end{array}$ & $\begin{array}{c}+++ \\
+++ \\
1.9 \\
0 \\
0 \\
++ \\
0.8 \\
++ \\
++ \\
1.1 \\
++ \\
0 \\
++ \\
+ \\
0 \\
++ \\
+ \\
2.2 \\
++ \\
+ \\
+ \\
++ \\
0.9 \\
++ \\
+ \\
1.0 \\
\ddot{1.2}\end{array}$ & $\begin{array}{c}+++ \\
+++ \\
2.5 \\
+ \\
1.5 \\
0 \\
++ \\
1.8 \\
++ \\
++ \\
2.0 \\
++ \\
++ \\
++ \\
+ \\
1.9 \\
++ \\
+ \\
2.6 \\
++ \\
+ \\
+ \\
++ \\
1.8 \\
++ \\
+ \\
1.8 \\
+++ \\
2.0\end{array}$ \\
\hline
\end{tabular}

Figures to the right and above the numbers indicating strains represent the number of animal passages, the asterisk ( ${ }^{*}$ ) that the strains ure jsoluted from the centers of gallstones. The rest of the strains were isolated from the walls of gallbladders. The + signs indicate roughly the degrees of acidity. The fgures indicate the number of cubic centimeters $\mathbf{N} / 10$ sodium hydrate required to neutralize 5 c.c. of the broth culture (phenolphthalein).

tionally, and incubated for 72 hours at $37 \mathrm{C}$. The number of + signs indicates roughly the degrees of acidity, with litmus or fuchsin as indicators. The figures indicate the number of cubic centimeters $\mathrm{N} / 10$ sodium hydrate required to neutralize 5 c.c. of broth culture (phenolphthalein). Unless otherwise indicated in Table 3 , the strains were isolated from the wall of the gallbladder itself. Altogether, 9 strains have been studied at intervals extending over a period of $11 / 2$ years. These include streptococci both from the wall of the gallbladder and from gallstones in 2 cases (Cases 58 and 91), and 3 strains before and after 1 animal passage. Lactose and salicin were fermented by all but 1 


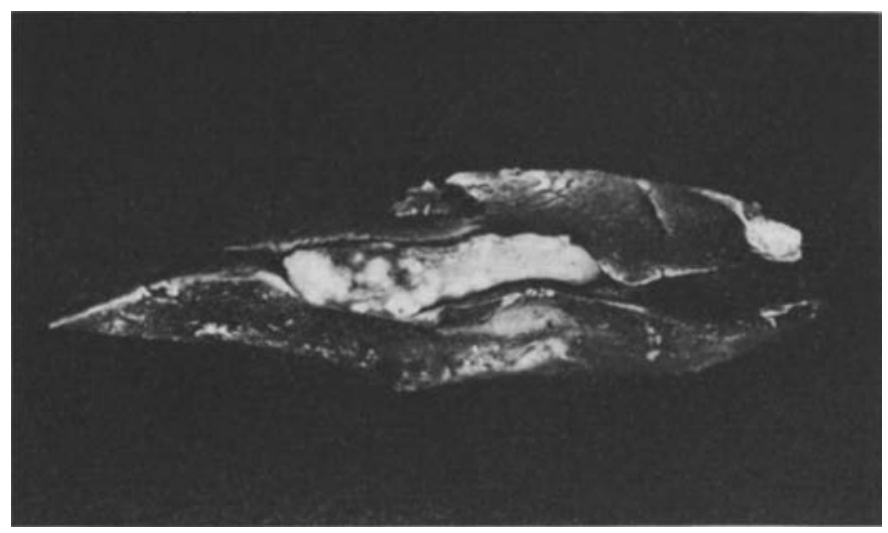

Fig. 18. Cholecystitis in a rabbit ( $R$ 407) 72 hours after intravenous injection of streptococci from ulcer of the stomach in a sheep (S 425). Natural size.

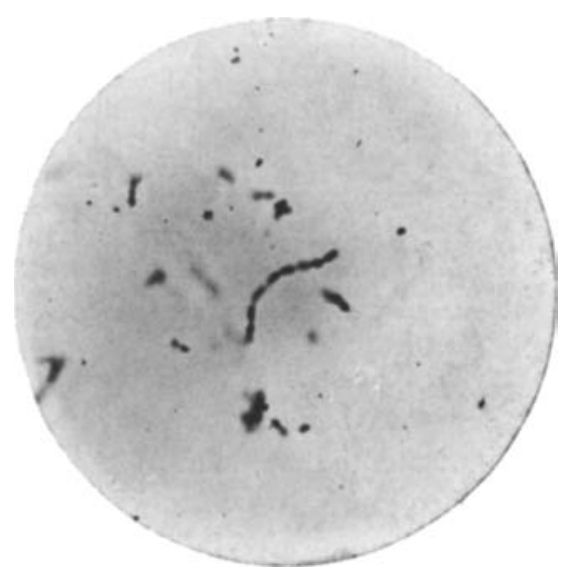

Fig. 19. Streptococci in the gallbladder of a rabbit (R 521) developing cholecystitis 6 days after intravenous injection of a streptococcus originally isolated as a pneumococcus. Strain $1.70 .{ }^{22} \times 1200$. 


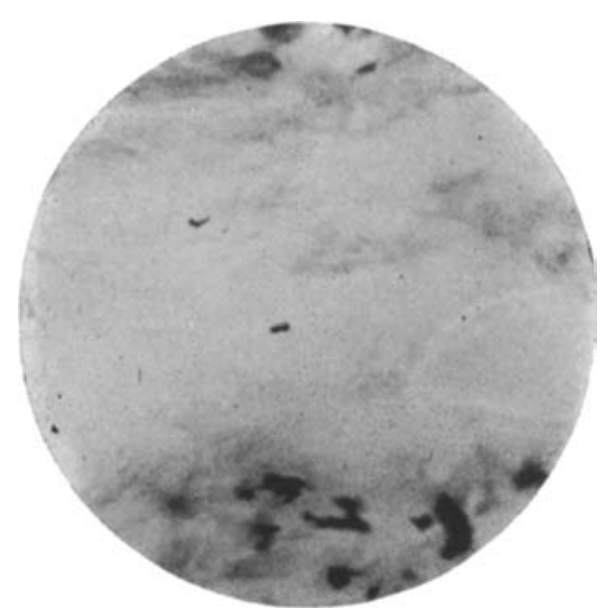

Fig. 20. Diplococci in the wall of a hemorrhagic area in the gallbladder of a dog (D 170) 24 hours after intravenous injection of a streptococeus from the thyroid gland in exophthalmic goiter (Case 80), after 1 animal passage. Gram.Weigert. $\times 1200$.

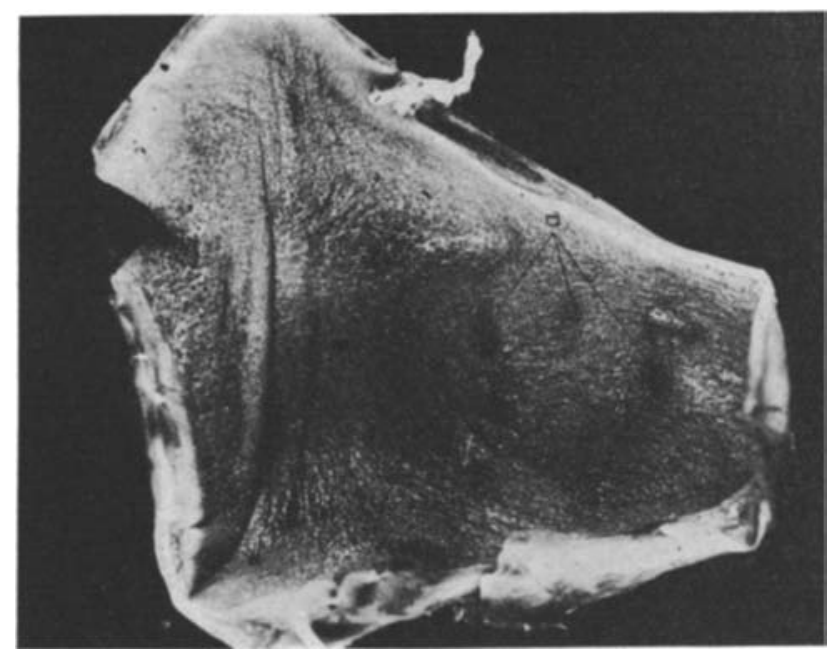

Fig. 21. Hemorrhagic and gangrenous cholecystitis in a dog (D 175) 24 hours after intravenous injection of a streptococcus from the thyroid giand in exophthalmic goiter (Case 80 ), after 2 animal passages. The areas of beginning gangrene are shown at $A$. Natural size. 
strain, mannite by all but 4 , saccharose by all but 2 , while raffinose was fermented only by 2 . The fermentative powers of strains from the centers of gallstones and from the corresponding walls of the gallbladders were identical; the fermentative powers of 1 strain only (Case 91), did not correspond on the different dates. 'Two of the strains after 1 animal passage showed the same fermentative powers as before (Cases 85 and 135), while 1 strain (Case 140) failed to ferment mannite after 1 animal passage.

The strains from the different cases showed a striking similarity and resembled closely the streptococci commonly found in ulcer of the stomach and appendicitis. They produced small moist grayishbrown or grayish-green nonadherent nonhemolyzing colonies on human blood agar; they produced short chains in liquid media with clumps of cocci somewhat resembling staphylococci (Fig. 8); they were of a rather low virulence, yet somewhat more virulent than the strains from gastric ulcer and appendicitis. Five of the strains had acquired distinct hemolytic powers from prolonged artificial cultivation on human blood agar. After animal passage they tended to produce more green on blood-agar plates. The loss of the power to infect the gallbladder electively occurred usually without demonstrable morphologic or cultural changes.

\section{SUMMARY AND GENERAL DISCUSSION}

The results thus detailed were obtained over a period of 2 years, in different localities, during different seasons of the year, and in different species of animals. The number of animals injected with some of the strains was sufficiently large to prove beyond doubt the elective property of strains isolated. Streptococci and colon bacilli from acute cholecystitis gave rise to more marked lesions in the gallbladders of dogs than did those from chronic cholecystitis. In some strains the virulence could be diminished by cultivation or increased by animal passage, and the affinity for the gallbladder still retained. Usually, however, this affinity was lost. Strains grown on artificial media acquired distinctly greater affinity for the stomach, and appendix; those passed through animals acquired affinity for the pancreas. ${ }^{11}$

In Case 120, ulcer was produced in animals with streptococci isolated from the lymph gland draining the duodenal ulcer, and cholecystitis was produced with streptococci from the gallbladder. These results furnish experimental evidence that ulcer and cholecystitis in the same patient at times may be due to hematogenous infection by streptococci which have these respective powers of localization. A single 
strain, however, may have affinity for both structures, as shown in numerous experiments.

The simultaneous occurrence of lesions in the gallbladder and in the cystic and common ducts following injection of the streptococcus from the gallbladder (Case 135) where these structures were involved, indicates that the lesions may be due to the wide range of affinity of the infecting micro-organism. The occurrence at the same time of cholecystitis and pancreatitis in the animals injected with bacteria from acute cholecystitis and pancreatitis (Case 166), and with strains from chronic cholecystitis and from ulcer after animal passage (Fig. 13), suggests that the simultaneous presence of the diseases in the same patient is due commonly in the beginning to hematogenous infections and not so often to lymphogenous or local invasion as the findings at operation so often appear to indicate. ${ }^{12}$

The demonstration of streptococci in the involved tissues in a high percentage of cases of chronic cholecystitis, the elective affinity of these organisms for the gallbladder in animals, and the production of the disease with the strains isolated from the experimental lesions, indicate that streptococci are a cause of cholecystitis. The importance not only of draining but of removing gallbladders is apparent, especially in the absence of stones, as already emphasized by Mayo $^{13}$ and others. This is especially true in cases of chronic cholecystitis. Gallbladders removed in chronic cholecystitis during the quiescent interval have been demonstrated to be the host of living bacteria. Might not the periodic exacerbations be due to resumption of activity on the part of a latent infection, when the defensive mechanism of the individual is low? The fact that streptococci which produced marked cholecystitis by systemic intravenous injection, failed to produce cholecystitis when injected into the radicles of the portal vein, or when injected directly into the gallbladder, is crucial evidence that cholecystitis in the absence of stones is very frequently hematogenous infection, and rarely the result of invasion from the bile.

The results of differential cultures in both spontaneous and experimental cholecystitis show that the colon bacillus is commonly a secondary invader in an infection with streptococci or in a mechanical injury produced by previously formed gallstones. That it is the primary cause of cholecystitis in some instances is quite certain, because one of a series of strains of the colon bacillus from cholecystitis was present in pure culture and showed elective affinity for the gallbladder in ani- 
mals (Case 230; Fig. 12). In one case, cholecystitis which had begun during convalescence in typhoid fever was proved to be due to streptococci, hence it would seem that cholecystitis occurring in typhoid fever is not always due to the typhoid bacillus.

The common presence of bacteria in the centers of gallstones, the formation of gallstones in association with cholecystitis following in jection of streptococci as observed in 9 instances, and the presence of the streptococci in the newly formed stones, emphasize anew the important rôle which infection plays in the etiology of gallstones. ${ }^{14}$ The almost complete absence of bacteria in the 4 pure cholesterin stones is in accord with the views of Aschoff, ${ }^{15}$ Henes, ${ }^{16}$ and others, who emphasize the importance of a high cholesteremia as a causative factor in the formation of gallstones. Streptococci have been isolated from the walls of gallbladders and demonstrated there in cases of chronic cholecystitis without stones. It would appear, therefore, that for the formation of gallstones 2 factors are usually necessary: (1) infection furnishing the nucleus for the precipitation of bile salts, etc., and (2) a concentrated bile of high cholesterol content.

\section{BIBLIOGRAPHY}

1. Blachstein: Bull. Johns Hopkins Hosp., 1891, 2, p. 96.

2. Welch: Ibid., p. 121.

3. Cushing: Ibid., 1899, 10, p. 166.

4. Koch: Ztschr. f. Hyg. u. Infektionskrankh., 1908-9, 62, p. 1.

5. Gay and Claypole: Arch. Int. Med., 1913, 12, p. 613.

6. Nichols: Jour. Exper. Med., 1914, 20, p. 573.

7. Rosenow: Jour. Infect. Dis., 1914, 14, p. 1.

8. Rosenow: Jour. Am. Med. Assn., 1914, 63, p. 1835.

9. Rosenow: Ibid., 1915,65 , p. 1687.

10. Rosenow: Ibid., 1914, 63, p. 903.

11. MacCarty: Ann. Surg., 1910, 51, 651.

12. Rosenow: Jour. Ind. State Med. Assn., 1915, 8, p. 458.

13. Mayo: Am. Jour. Med. Sc., 1914, 147, p. 469.

14. Mignot: Arch. gén. de méd., 1898, 2, pp. 129, 263.

15. Aschoff: Wien. klin. Wchnschr., 1911, 24, p. 559.

16. Henes: Jour. Am. Med. Assn., 1914, 63, p. 146. 